\title{
CONCENTRATION, DIVERSITY, AND MANUFACTURING PERFORMANCE
}

\author{
by \\ Joshua Drucker * \\ University of Illinois at Chicago
}

CES 10-14 July, 2010

The research program of the Center for Economic Studies (CES) produces a wide range of economic analyses to improve the statistical programs of the U.S. Census Bureau. Many of these analyses take the form of CES research papers. The papers have not undergone the review accorded Census Bureau publications and no endorsement should be inferred. Any opinions and conclusions expressed herein are those of the author(s) and do not necessarily represent the views of the U.S. Census Bureau. All results have been reviewed to ensure that no confidential information is disclosed. Republication in whole or part must be cleared with the authors.

To obtain information about the series, see www.ces.census.gov or contact Cheryl Grim, Editor, Discussion Papers, U.S. Census Bureau, Center for Economic Studies 2K130B, 4600 Silver Hill Road, Washington, DC 20233, CES.Papers.List@census.gov. 


\begin{abstract}
Regional economist Benjamin Chinitz was one of the most successful proponents of the idea that regional industrial structure is an important determinant of economic performance. His influential article in the American Economic Review in 1961 prompted substantial research measuring industrial structure at the regional scale and examining its relationships to economic outcomes. A considerable portion of this work operationalized the concept of regional industrial structure as sectoral diversity, the degree to which the composition of an economy is spread across heterogeneous activities. Diversity is a relatively simple construct to measure and interpret, but does not capture the implications of Chinitz's ideas fully. The structure within regional industries may also influence the performance of business enterprises. In particular, regional intra-industry concentration - the extent to which an industry is dominated by a few relatively large firms in a locality-has not appeared in empirical work studying economic performance apart from individual case studies, principally because accurately measuring concentration within a regional industry requires firm-level information. Multiple establishments of varying sizes in a given locality may be part of the same firm. Therefore, secondary data sources on establishment size distributions (such as County Business Patterns or aggregated information from the Census of Manufactures) can yield only deceptive portrayals of the level of regional industrial concentration. This paper uses the Longitudinal Research Database, a confidential establishment-level dataset compiled by the United States Census Bureau, to compare the influences of industrial diversity and intra-industry concentration upon regional and firm-level economic outcomes. Manufacturing establishments are aggregated into firms and several indicators of regional industrial concentration are calculated at multiple levels of industrial aggregation. These concentration indicators, along with a regional sectoral diversity measure, are related to employment change over time and incorporated into plant productivity estimations, in order to examine and distinguish the relationships between the differing aspects of regional industrial structure and economic performance. A better understanding of the particular links between regional industrial structure and economic performance can be used to improve economic development planning efforts. With continuing economic restructuring and associated workforce dislocation in the United States and worldwide, industrial concentration and over-specialization are separate mechanisms by which regions may "lock in" to particular competencies and limit the capacity to adjust quickly and efficiently to changing markets and technologies. The most appropriate and effective policies for improving economic adaptability should reflect the structural characteristics that limit flexibility. This paper gauges the consequences of distinct facets of regional industrial structure, adding new depth to the study of regional industries by economic development planners and researchers.

* This work has been supported by awards from the National Science Foundation (BCS0423900), the Ewing Marion Kauffman Foundation, and the North American Regional Science Council. Any opinions and conclusions expressed herein are those of the author and do not necessarily represent the views of the United States Census Bureau or any of the supporting organizations. All results have been reviewed to ensure that no confidential information is disclosed. Support for this research at the Triangle Census Research Data Center from the National Science Foundation (ITR-0427889) is also gratefully acknowledged.
\end{abstract}




\section{Introduction}

The relationship between industrial structure and economic performance has long interested researchers in a number of fields, including geography, economics, regional science, and economic development planning. Many aspects of industrial structure-from firm or establishment size and overall industry scale to market power and interfirm patterns of competition and cooperation-have been studied, sometimes in relation to one another but more often separately. Some structural traits have been examined in great depth and breadth; others much less thoroughly, depending on attributes such as theoretical pertinence, interpretability, perceived or hypothesized importance, and data availability. The outcome is a plethora of results and interpretations, confusing not only for academics attempting to classify and measure the relationships between industrial structure and performance, but also for practitioners interested in analyzing the strengths and shortcomings of particular economies in order to inform the design of economic development policy.

This paper compares two aspects of regional industrial structure within the United States manufacturing sector that may affect economic performance. Industrial or economic diversity, defined as the variety of heterogeneous activities comprising an economy at a specific time, has been investigated at least since the 1930s in the United States (Malizia and Ke 1993). Industrial concentration is the extent to which the economic activity of an industry or industrial sector is accounted for by one or a few large firms. In contrast to diversity, industrial concentration has not been systematically explored at the regional level in the United States, largely due to the fact that its accurate assessment requires firm- or establishment-level information. Because firms may encompass multiple establishments of varying sizes in a given locality, publicly available secondary data sources (such as County Business Patterns or the Census of Manufactures) are inadequate for gauging regional industrial concentration. This study employs the Longitudinal Research Database (LRD), a confidential plant-level dataset compiled by the United States Census Bureau that contains detailed information on location, industry classification, employment, and inputs and outputs for nearly all manufacturing establishments nationwide.

This analysis fits within a larger body of work using a variety of research approaches to investigate regional industrial concentration. Earlier work explores the empirical incidence of industrial concentration over time and across different regions of the United States, and models 
the relationship between industrial concentration and economic performance at both the plant and industry levels (Drucker and Feser 2007; Drucker 2009). This paper explicitly compares industrial concentration with the more well-studied trait of industrial diversity in order to enhance empirical knowledge concerning the impacts of industrial structure at the regional scale.

Understanding and evaluating regional industrial structure has important practical applications. Industrial concentration and over-specialization (i.e., the lack of industrial diversity) are two different mechanisms by which regions may "lock in" to a particular set of competencies (Christopherson and Clark 2007). As markets evolve and technology changes, those competencies, once key economic engines, eventually may become economic liabilities and limit industrial flexibility (Grabher 1993; Bergman 2002). Smaller regions and "onecompany towns" are exceptionally vulnerable to such dynamics, as are larger regions that lack industrial diversity, but industrial concentration may constrain adaptability in many different types of industries and regions. The implications for regional economic performance, and related policy formulation are especially consequential given ongoing industrial restructuring and associated workforce dislocation in the United States, as well as continuing trends toward offshoring both labor- and technology-intensive economic activity. Policies intended to boost economic adaptability and resiliency are most likely to be effective if they reflect a knowledge of the particular structural characteristics that limit these desirable characteristics.

The next segment of the paper offers a brief overview of existing research on regional industrial structure, concentrating on the two characteristics of diversity and concentration. The following section describes the data sources and the construction of the industrial structure indicators and other variables. The empirical analyses span three different levels of industrial aggregation. The relationships between industrial structure and employment change are examined using exploratory regressions for both the manufacturing sector as a whole and for component industry subsectors. Then production functions estimated for three selected manufacturing industries reveal the impacts of industrial concentration and diversity on plantlevel productivity. The paper concludes by summarizing the findings and suggesting implications for policy and directions for future research. 


\section{Background and Previous Research}

Industrial diversity has been one of the most commonly studied regional structural features in developed nations (Malizia and Ke 1993). There are several ways in which greater industrial diversity has been postulated to contribute to regional economic performance; each has garnered substantial empirical support. Analogously to an investment portfolio, the greater the variety of activities in a region, the more overall resiliency there is with respect to shocks or downturns occurring in any individual industry or segment (Conroy 1975; Brewer 1985; Frenken et al. 2007). In addition, greater diversity reduces the chance of local employment being concentrated in a particularly unstable or declining industry (Malizia and Ke 1993). Industrial diversity supports a wider range of local inputs and services (Scott 1988b), while diversity of employment opportunities reduces frictional unemployment (Izraeli and Murphy 2003; Mizuno et al. 2006). Jacobs (1969) argues that the cross-fertilization of ideas across industries enabled by diversity is crucial for regional economic dynamism. Such inter-industry spillovers are sometimes termed "Jacobs externalities" and have been tested repeatedly in comparison to Marshall's ([1890] 1910) concept of intra-industry knowledge spillovers (Glaeser et al. 1992; Henderson et al. 1995; Lee et al. 2005). In the long run, these benefits may lead to additional advantageous outcomes associated with general economic good fortune, such as long-term employment growth, firm births, increased innovation, and expansion of regional labor productivity and population (e.g., Friedman 1995; Quigley 1998; Feldman and Audretsch 1999; Hanson 2001; Armington and Acs 2002; Essletzbichler and Rigby 2002; Dissart 2003; Henderson 2003; Holl 2004b; 2004a; Rosenthal and Strange 2004; Lall and Chakravorty 2005; Shearmur and Polese 2007).

The set of features considered in the literature has expanded since researchers first began to consider and investigate regional industrial structure. In 1961, regional economist Benjamin Chinitz reinvigorated interest in industrial structure and its relationship to economic performance at the regional scale (e.g., see Glaeser et al. 1992; Gerking 1994; Hanson 2001). In drawing a stark contrast between the economic conditions in place in the Pittsburgh and New York metropolitan areas in the 1950s, Chinitz described or implied several distinguishable structural features: the absolute size of regional industries, the extent of sectoral diversity in the regional economy, and the degree to which one or a few large firms dominate the regional business community. 
Subsequent authors have followed several paths in interpreting and measuring empirically the structural concepts discussed by Chinitz. Carlino (1980; 1987), for example, argued that Chinitz intended to emphasize regional industrial diversity, exemplified by New York and illustrated via counterexample in the case of steel-dominated Pittsburgh. Innovative studies have continued to add to the preponderance of evidence that industrial diversity is related to a variety of positive economic qualities, as described earlier. Evans (1986) and Norton (1992), in their readings of Chinitz, instead stressed average firm size. Investigations following this path have uncovered relationships between smaller firm or plant size and a broad range of desirable outcomes, including firm births and growth, technology and innovation adoption, active entrepreneurship, firm births in customer industries, and productive efficiency (e.g., Acs and Audretsch 1990; Harrison et al. 1996; Combes 2000; Acs and Armington 2004; Loveridge and Nizalov 2007; Glaeser and Kerr 2008). Other research has focused on overall industry size, typically conceptualized as capturing a localization economy effect and benefitting productivity, profitability, growth, innovation, and attracting firms making location choices (e.g., Moomaw 1986; Henderson et al. 1995; Henderson 1997; Feser 2001; Desmet and Fafchamps 2005; Kambhampati and McCann 2007). Each of these traits offers a useful but necessarily partial representation of regional industrial structure.

A separate question raised by Chinitz is whether the domination of a particular industry or sector by a few companies in a locality influences the performance of the other enterprises, particularly small or entrepreneurial businesses, in the same regional industry or sector. The 1950s Pittsburgh economy dominated by steel manufacturing epitomizes this situation, yet concentration may also affect adaptability in industries that are not the largest, most visible, or most central in their regional economies. Metropolitan Charlotte in North and South Carolina, known for banking and finance, has a small but highly concentrated device manufacturing industry. Jobs are much more concentrated in several large firms in the plastics manufacturing industry in Des Moines, Iowa, than in the comparably-sized Toledo, Ohio, plastics industry. Such examples exist across the United States, and detailed case studies have examined industrial structures in specific regions or regional industries (e.g., Scott 1988b; Saxenian 1994b; Enright 1995b; Gort and Sung 1999; Rantisi 2002; Watts et al. 2003). Yet this structural featureregional industrial concentration — has not been investigated systematically outside of case studies, principally due to the unavailability of firm-level data. (It can be argued that average 
plant size, as an indicator of the establishment size distribution that is calculable from publicly available information, acts as a rudimentary proxy for concentration.) While the literature examining industry scale, industrial diversity, and average plant size yields useful information and insights, these notions are not sufficient to represent the phenomenon of regional industrial concentration. In particular, concentration may have separate implications for the economic dynamics of the majority of regions that neither experience overriding economic dominance by a single firm or industry nor possess approximately competitive markets in each industry.

There are numerous mechanisms described in the literature through which industrial concentration may affect the economic performance of regional industries. Industrial concentration may limit locally available external economies, as large firms tend to be more vertically integrated and are more likely to purchase inputs from nonlocal suppliers, curtailing accessible markets for specialized suppliers to serve other industry firms (Scott 1986; Scott 1988a; Scott and Kwok 1989; Mason 1991; Enright 1995a; Porter 1998; Henderson et al. 2001). Producers of specialized inputs and services favor the stability of large volume contracts and attend first to those purchasers with greater buying power at the expense of smaller firms (Nelson and Winter 1982; Booth 1986). Suppliers serving several different industries may perceive less risk in adapting products for an industry with many rivals than for one dominated by one or a few enterprises. Labor, particularly workers with specialized training, tends to gravitate toward locally dominant, stable employers (Audretsch 2001a), but potential job seekers are more likely to invest in obtaining industry-specific skills in the presence of rivalrous firms (Porter 1990). Public goods and specialized information are more likely to be available or tailored toward particular industry needs in regions in which an industry is competitively structured (Porter 1998; Mukkala 2004). Interfirm networking and group learning opportunities tend to be superior in an environment with many small, independent establishments (Malecki 1994; Carree and Thurik 1999; Gordon and McCann 2000; Helmsing 2001). Bureaucratic management structured to retain control over employees and maximize efficiency tends to inhibit innovation and spin-offs (Booth 1986; Saxenian 1994a), whereas a competitive industrial environment encourages more risk-taking behavior, boosting knowledge spillovers (Scherer 1980; Porter 1990; Malmberg and Maskell 2002). Some of these mechanisms likely operate to a degree among related industries as well as upon the firms in the regionally concentrated industry. 
Industrial concentration may also present economic advantages. Large firms may serve as regional industry anchors, attracting specialized labor and intermediate suppliers to the region that then also benefit smaller firms in the industry (Feldman 2003). Established firms generate knowledge and technology spillovers that can provide opportunities for fledgling enterprises (Agrawal and Cockburn 2003). The relative mix of advantage versus disadvantage presented by regional industrial concentration may vary with firm and industrial life cycles as well as the level of maturity of the regional economy (Duranton and Puga 2001).

Although industrial concentration has not been studied comprehensively at the regional level, there is a substantial body of work within the field of industrial organization investigating firm sizes and concentration at national scales. In 1931, Robert Gibrat observed that the size distribution of French manufacturing plants was highly skewed, a pattern that has proved highly robust across industrialized nations, over time, and for different definitions of size (Collins and Preston 1961; Ijiri and Simon 1977; Stanley et al. 1995; Axtell 2001). Because skew distributions (such as the Yule and Pareto distributions) are encountered in diverse settings, from biology to astronomy to literature, researchers have sought broad theoretical mechanisms as explanations (Ijiri and Simon 1977; Sutton 1997; Caves 1998; Audretsch 2001b). The dynamics of entry and exit, for example, are applicable to a variety of economic as well as non-economic phenomena. Gibrat himself suggested that the pattern of French manufacturing plant sizes might be explained by firm growth rates being independent of the firm size already attained, a proposition that has come to be known as Gibrat's Law of Proportional Effect (Sutton 1997).

Unfortunately, the majority of industrial organization research surrounding the topic of firm size distributions is not directly applicable to the issue at hand. Since Gibrat's initial foray, the subject of the firm size distribution has received less attention than many other more prominent topics in industrial organization, in part because a thorough investigation necessitates large amounts of data available at a disaggregate level or is subject to aggregation bias (Sutton 1997; Bottazzi and Secchi 2003; Gans and Quiggin 2003). In addition, most industrial organization research fails to consider location or spatial variation as a relevant factor, instead emphasizing idiosyncratic or sector-specific explanations of observed industry differences (Schmalensee 1989; Davies and Geroski 1997). A few rare cross-industry studies conducted at the national level provide some evidence that the relationship between industrial concentration and firm performance is nonlinear (Caves and Barton 1990; Gopinath et al. 2004) and that 
employment concentration in large firms may boost productivity growth (Acs et al. 1999).

Moreover, the prevailing methodological approach—matching precisely defined distributions to empirical phenomena—sets up "extreme" hypotheses that cannot be evaluated with standard inferential statistics (Ijiri and Simon 1977; Powell 2003). The alternative is to measure firm size distributions with indicators rather than fitting fully specified distributions. Measures of concentration based on size traits such as employment or sales have been examined extensively in relation to profit rates, productivity, and innovation intensity (Cohen and Levin 1989; Schmalensee 1989; Caves and Barton 1990; Vossen 1999; Gopinath et al. 2004). Although this tactic entails complications, as there are multiple candidate indicators possessing different properties (Needham 1978), it offers an approach useful for this study.

To recapitulate, studies conducted over the greater part of a century present substantial evidence of relationships between regional industrial diversity and a variety of desirable economic outcomes. Similarly, empirical research links structural features such as small average firm size and overall industry scale to economic qualities such as growth, dynamicism, and productiveness. The conceptually distinct phenomenon of industrial concentration may have major influence as well, but has not been examined systematically at the regional scale outside of case studies. Although concentration has received some attention in the industrial organization literature, it has been at the national scale and employing aspatial approaches. As a practical consideration, the difficulties encountered in attempting to fit fully-specified firm size distributions suggest the value of using summary indicators in this research.

\section{Data Sources and Methodology}

\section{$\underline{\text { Plant-Level Data }}$}

The accurate measurement of regional industrial concentration requires information concerning individual establishments or firms. The principal data source for this study is the Longitudinal Research Database (LRD). The LRD is compiled by the United States Census Bureau from confidential establishment-level records collected for the quinquennial Census of Manufactures (CM) and the Annual Survey of Manufactures (ASM), and contains detailed information on establishment locations (counties), primary industry classification, and other establishment characteristics. [See McGuckin (1990) for database construction and content 
details.] Coverage starts in 1963 and presently stretches to the 2002 Census and the 2005 Survey. After 1997, the North American Industrial Classification System (NAICS) replaced the Standard Industrial Classification (SIC) system. Changes in industry definitions preclude analyzing industries or sectors across the break, so the exploratory regressions focus on the period from 1987 to 1997, the most recent decade available prior to the classification switch.

Although the LRD includes entries for all U.S. establishments reporting under a manufacturing industry code, the coverage of most data items is incomplete for small establishments in non-census years. ${ }^{1}$ Since this study focuses on the distributions of large and small establishments, only data from census years of the LRD are used in order to obtain the most accurate balance among establishment sizes. Establishments reporting zero employment are excluded from all of the analyses; establishments exempt from complete filing requirements (typically those with five or fewer employees) are included in the exploratory regressions but not the productivity analysis since they do not report directly on production inputs.

The LRD is compiled from confidential records, and use of the dataset and release of descriptive statistics and results obtained from its analysis are strictly regulated. All of the information presented has been reviewed by Census Bureau staff to ensure confidentiality. Because confidentiality restrictions and disclosure screening requirements limit the types and quantity of information possible to extract, in some places qualitative descriptions replace numerical tabulations or other quantitative information.

\section{$\underline{\text { Regions }}$}

For the exploratory regressions, the regions are the 1999 Metropolitan Statistical Areas (MSAs) and Consolidated MSAs (CMSAs) (United States Census Bureau 2002). Metropolitan areas are appropriate units for examining regional industrial interactions because they approximate functional economic areas across which industrial structures may be expected to influence interfirm interactions. Alaskan and Hawaiian regions are omitted due to their isolated locations. The first analysis examines all of the 275 MSAs and CMSAs in the contiguous United

\footnotetext{
${ }^{1}$ The ASM is a five-year panel sample of plants with rotating membership. Only large plants (normally those with at least 250 employees) are included with certainty; the remainder of the sample is selected randomly to reduce data gathering costs and reporting burdens. Sample weights support imputations to national industries or entire manufacturing sectors, but not to industries at the regional scale. In any given year the ASM includes less than 20 percent of United States manufacturing plants. (Thus, despite its name, the LRD is not a longitudinal database at the establishment level.)
} 
States. In the following section, regions with fewer than twelve firms in the industrial sector being examined are omitted, so that the number and distribution of regions included varies by industrial subsector. Disclosure restrictions preclude divulging the particular regions by industry.

In the productivity analysis, the geographic regions are defined as U.S. Department of Agriculture Labor Market Areas (LMAs) (2003), which approximate functional economic areas and cover the lower 48 states completely. ${ }^{2}$ The LMAs of central New York, Los Angeles, and Chicago are excluded as outliers because of those regions' strong focus on national and global rather than local linkages and interfirm relationships. ${ }^{3}$

\section{Industrial Concentration}

Earlier work conducted at the national scale has employed a variety of summary indicators of industrial concentration or market power, typically calculated from employment or sales figures (Hay and Morris 1991; Pryor 2001; Powell and Lloyd 2005). Empirical comparisons demonstrate that no single measure is consistently superior (Amato 1995). This study uses four employment-based measures, regional analogues of those found in the industrial organization literature: a five-firm concentration ratio, the Herfindahl-Hirschman index, the Rosenbluth index, and Theil's entropy.

Concentration ratios are probably the most widely used measure of industrial concentration, partly because they are available from the United States Census Bureau at the national level in public-release versions of the Census of Manufactures (Golan et al. 1996). For this research, the concentration ratio carries the advantage that it is relatively insensitive to the pattern of firm sizes at the low end of the distribution, which accords with the conception of dominance as the degree to which an entire industry is influenced by a few large firms. Therefore, the principal measure examined in this analysis is a five-firm concentration ratio. Establishments are first aggregated to the level of firms based on the same-industry same-region manufacturing components of multi-unit firms. The concentration ratio measure is then the ratio of employment in the five largest firms to total regional employment in the industry. Because

\footnotetext{
${ }^{2}$ Although the LMAs are less recognizable than MSAs and CMSAs, it is advantageous to include lower density areas in working with four-digit SIC industries rather than broad industrial sectors in order to maximize the variation in structural characteristics across regions.

${ }^{3}$ Alternative estimations including these three LMAs yielded substantively similar but weaker results.
} 
regional industrial concentration is only meaningful in situations in which "dominant" companies can be distinguished from a larger set of influenced firms, regions containing fewer than twelve firms in the industry or industrial sector being examined are excluded.

Industrial concentration can be gauged by indices constructed from the full set of firm size shares. Some economists contend that such measures are preferable precisely because they do take into account the entire firm size distribution and thus are sensitive to both the total number of firms and the relative distribution of size among firms; concentration ratios depend on only one point in the size distribution (Hay and Morris 1991). The indices used in this paper are distinguished by the scheme for weighting firm size shares. The Herfindahl-Hirschman index weights each size share proportionally to firm size, by summing the squared firm shares of regional industry employment. These weights emphasize the largest firms, so the index is insensitive to the size distribution among the smaller firms. Theil's entropy measure weights by the natural logarithm of the size shares, reducing the emphasis placed on the largest firms (Attaran and Saghafi 1988). The Rosenbluth index instead weights by descending firm size rank, stressing the small end of the firm size distribution. For all three measures, the minimum of twelve industry firms is imposed to preserve the meaningfulness of the concentration variable, and to maintain identical estimation samples across the different concentration measures.

Table 1 lists the four industrial concentration measures, their formulae, and theoretical ranges. Except for Theil's entropy, larger values of each index reflect greater regional industrial concentration. Theil's entropy is reversed: the more closely the measure approaches zero, the greater the degree of concentration. Appendix Table 1 contains the mean and standard deviations of the four concentration measures across the manufacturing sector.

\section{$\underline{\text { Industrial Diversity }}$}

Industrial diversity is captured with a Herfindahl-Hirschman index, a standard approach in the empirical literature. The formula is identical to that provided in Table 1, but with the subscript $i$ indexing four-digit SIC industries within the manufacturing sector rather than individual firms. The Herfindahl-Hirschman index corresponds inversely to diversity, so that larger values signify greater concentration within industries and less manufacturing diversity. 
Table 1. Regional Industrial Concentration Measures.

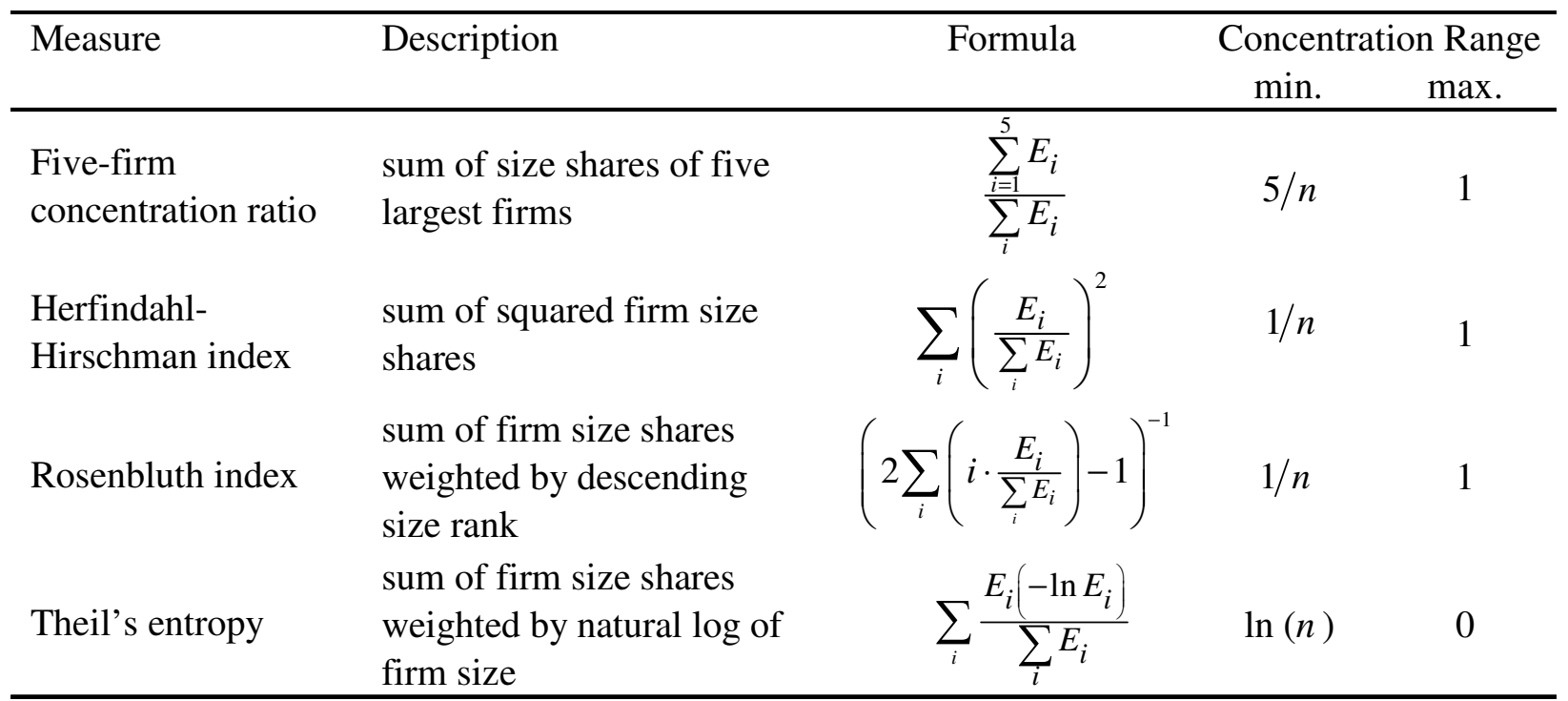

Note: $n$ is the number of firms in the regional industry, $i$ indexes the firms in the regional industry in descending size order, and $E_{i}$ represents the employment of the ith firm.

\section{Empirical Approaches}

It is constructive to explore the impacts of regional industrial concentration at several levels of industry aggregation, both because the phenomenon has not been systematically investigated and because the mechanisms by which concentration influences economic performance may shift or operate differently as the degree of industrial similarity changes. The next section describes regression analyses that relate industrial structure to employment change for the manufacturing sector considered as a whole. Then the approach is applied to the industrial subsectors that comprise the manufacturing sector. Employment is an aspect of economic performance that is particularly relevant to policymakers and is highly appropriate as a measure at the scale of regions rather than individual firms. The regressions are exploratory in nature: they are not full specifications for predicting regional industry employment, but rather suggest the relative influence that industrial concentration and diversity have on employment changes occurring over time. In these sections, the relevant question is whether a few large companies dominate either the entirety of or large components of the regional manufacturing sector, and how important that influence is on employment vis-à-vis the relative diversity of sectoral composition.

The final empirical section engages a different methodology, focusing on three specific 
manufacturing industries and estimating plant-level production function models that incorporate measures of regional industrial structure along with various controls. At the industry level, regional industrial concentration refers to the extent to which one or a small number of firms dominate the production of a particular output in a region. Unlike in the previous sections, the models are fully specified according to economic and regional theory. This approach not only focuses on more cohesive and homogeneous groups of manufacturing plants, but also illuminates a different aspect of economic performance_productivity_that may not coincide with employment change, especially during a period of restructuring and consolidation.

\section{Concentration and Diversity across the Manufacturing Sector}

Table 2 reports the results of a regression conducted using the 275 MSA and CMSA observations as the units of analysis. The dependent variable is the change in regional manufacturing employment from 1987 to 1997. This decade is the most recent ten-year period available for analysis that avoids the discontinuity in industry classification schemes (switching from the Standard Industrial Classification to the North American Industry Classification System) subsequent to 1997. The key independent variables are regional manufacturing concentration as indicated by the five-firm concentration ratio measure and regional manufacturing diversity. The level of manufacturing employment in 1987 is included to account for the differing sizes of the manufacturing sectors across metropolitan regions and to control for the national trend. Additional control (dummy) variables indicate Census Regions, with the Northeast as the default. White's general heteroskedasticity test does not reject homoskedasticity at conventional significance levels, and the heteroskedasticity-adjusted probability values are little different from the standard estimates. ${ }^{4}$

Because the set of units upon which the regression is calculated comprise a population rather than a representative sample, statistical significance is not relevant in reference to a larger population. Standard errors and probability values are examined to gauge the reliability of the estimated coefficients relative to the variation in the observed data rather for making inferences.

\footnotetext{
${ }^{4}$ Alternate specifications that were tested but are not presented here include measuring the dependent variable as the percentage change in employment, substituting firm counts or total value added for employment in the dependent variable, adding lagged concentration and diversity measures, specifying dummies for Census Divisions rather than Census Regions, and breaking the decade into two five-year intervals. Each of these specifications produced results that support the substantive findings and interpretations described in the text.
} 
Table 2. Regression Results: Manufacturing Sector.

\begin{tabular}{lrrrcc}
\hline Variable & Coeff. & Std. Err. & t Stat. & p Value & White p Value \\
\hline Dependent Variable: Employment Change, & 1987-1997 & & & & \\
Intercept & 15,100 & 3,514 & 4.30 & $<.0001 * *$ & $0.0004 * *$ \\
1987 Concentration (Concentration Ratio) & $-29,760$ & 9,145 & -3.25 & $0.0013 * *$ & $0.0003 * *$ \\
1987 Diversity (Herfindahl-Hirschman) & 9,231 & 19,007 & 0.49 & 0.6276 & 0.3150 \\
1987 Manufacturing Employment & -0.183 & 0.0092 & -19.97 & $<.0001 * *$ & $0.0002 * *$ \\
South & 1,754 & 2,610 & 0.67 & 0.5020 & 0.3145 \\
Midwest & 4,803 & 4,022 & 1.19 & 0.2334 & 0.1118 \\
West & 6,444 & 3,263 & 1.98 & $0.0493 *$ & 0.0809 \\
Observations & 275 & & F Stat. & & 71.88 \\
$\mathrm{R}^{2}$ & 0.6168 & & F Prob. & & $<.0001$ \\
Adjusted R & 0.6082 & & & & \\
\hline
\end{tabular}

* Significant at the 5\% confidence level. ** Significant at the $1 \%$ confidence level.

Moreover, since the independent variables are not normalized, the substantive meaning in the exploratory regression is found in the signs and relative strength of the estimated parameters as indicated by significance measures, rather than the raw coefficient magnitudes.

Regional manufacturing concentration is substantially and negatively associated with employment change. All else equal, a region one standard deviation higher than the mean with regard to the concentration ratio measure would be expected to have lost approximately 5,100 more manufacturing jobs over the decade than a region with the mean industrial concentration level in 1987 (a concentration ratio of 0.566 versus 0.394; see Appendix Table 1). Because the regression includes the 1987 regional manufacturing employment as a control variable, this figure can be interpreted as independent of the starting size of the sector.

Industrial diversity within the manufacturing sector is negatively but not significantly associated with gains in employment. Although the estimated coefficient is large in magnitude, the Herfindahl-Hirschman index has a relatively small sample mean, and the large probability value indicates the weakness of the estimated regression parameter. A standard deviation increase in industrial diversity above the average is associated with an employment change of less than a fifth of the 5,100 increase calculated for manufacturing concentration. ${ }^{5}$ Moreover, the sign of the parameter estimate is counter to theoretical expectations (recall that as constructed, the Herfindahl-Hirschman index measure corresponds inversely to diversity_larger values

\footnotetext{
${ }^{5}$ A more precise figure would require descriptive statistics for the industrial diversity measure that have not been approved for release.
} 
signify lesser degrees of manufacturing diversity.) The relative weakness of the influence may be explained partly by the limited variation the diversity variable exhibits across metropolitan regions. Another explanation is the negative correlation between regional manufacturing concentration and diversity: industrially concentrated regions tend not to be diverse, and diverse areas are usually less concentrated. ${ }^{6}$ This relationship is related to regional size, as large regions typically possess greater industrial diversity. Overall, the evidence indicates that industrial concentration is more powerfully linked to employment change than is industrial diversity.

As for the control variables, the 1987 count of manufacturing employees is negative and highly significant. This is to be expected: in a period of manufacturing decline at the national level, regions with larger manufacturing sectors tended to shed more employment. Southern, Midwestern, and particularly Western areas experienced greater employment growth, or smaller drops in the number of manufacturing jobs, than Northeastern metropolitan regions.

Substituting the other concentration measures for the five-firm concentration ratio produces the results displayed in Table 3. The estimated job changes from 1987 to 1997 associated with an increase in manufacturing concentration of one standard deviation are compared in Table 4. The Rosenbluth measure yields results very similar to the five-firm concentration ratio, suggesting that at the sectoral level the large firm end of the size distribution is the crucial portion. The relationship between the Herfindahl-Hirschman index measure of concentration and manufacturing job change is smaller and weaker than for the other concentration measures, perhaps diminished by the similarity in construction of the concentration and diversity variables. Theil's entropy measure evinces a more substantial relationship with job change. This extent of deviation across measures — within an order of magnitude-is not unexpected in an exploratory regression, particularly as the degree of variation across regions is dissimilar. The estimated coefficients of industrial diversity, on the other hand, vary widely in strength, and even in sign, whereas the coefficients of the control variables do not differ notably from Table 2. The conclusion that industrial concentration but not diversity is tied to manufacturing employment performance over time holds across all four of the tested concentration indicators.

An additional experiment lends extra weight to the main finding described above. Table 5 presents the results obtained by alternately omitting industrial concentration and diversity from

\footnotetext{
${ }^{6}$ Regional descriptive statistics and correlations have not been approved for disclosure.
} 
Table 3. Regression Results: Manufacturing Sector, Alternative Concentration Measures.

\begin{tabular}{|c|c|c|c|c|c|c|}
\hline \multirow[b]{2}{*}{ Variable } & \multicolumn{2}{|c|}{ Herfindahl-Hirschman } & \multicolumn{2}{|c|}{ Rosenbluth } & \multicolumn{2}{|c|}{ Theil's Entropy } \\
\hline & Coeff. & $\mathrm{p}$ Value & Coeff. & $\mathrm{p}$ Value & Coeff. & $\mathrm{p}$ Value \\
\hline \multicolumn{7}{|c|}{$\begin{array}{l}\text { Dependent Variable: } \\
\text { Employment Change, 1987-1997 }\end{array}$} \\
\hline Intercept & 9,128 & $0.0058 * *$ & 8,943 & $0.0048 * *$ & $-35,970$ & $<.0001 * *$ \\
\hline 1987 Concentration & $-28,976$ & 0.2282 & $-184,853$ & $0.0004 * *$ & 9,004 & $<.0001 * *$ \\
\hline 1987 Diversity & $-13,353$ & 0.5308 & 2,924 & 0.8641 & 29,831 & 0.0801 \\
\hline 1987 Manuf. Employment & -0.175 & $<.0001 * *$ & -0.181 & $<.0001 * *$ & -0.218 & $<.0001 * *$ \\
\hline South & 834 & 0.7531 & 2,372 & 0.3651 & 2,996 & 0.2336 \\
\hline Midwest & 4,125 & 0.3135 & 5,385 & 0.1808 & 3,855 & 0.1305 \\
\hline West & 6,214 & 0.0660 & 7,055 & $0.0306 *$ & 6,342 & $0.0431 *$ \\
\hline Observations & 275 & & 275 & & 275 & \\
\hline $\mathrm{R}^{2}$ & 0.6038 & & 0.6202 & & 0.6489 & \\
\hline Adjusted $\mathrm{R}^{2}$ & 0.5949 & & 0.6117 & & 0.6410 & \\
\hline
\end{tabular}

* Significant at the 5\% confidence level. ** Significant at the $1 \%$ confidence level.

Table 4. Estimated Effect of Standard Deviation Increase in Manufacturing Concentration.

\begin{tabular}{lc}
\hline Measure & Job Change, 1987-1997 \\
\hline Five-Firm Concentration Ratio & $-5,107$ \\
Herfindahl-Hirschman Index & $-2,025$ \\
Rosenbluth Index & $-4,991$ \\
Theil's Entropy & $-10,320$ \\
\hline
\end{tabular}

the regression. (Only the coefficients of concentration and diversity are displayed; the other estimated parameters remain substantively similar to those in Tables 2 and 3.) With only one structural variable included, the estimated relationship between employment change and any of the concentration measures is stronger than between employment change and diversity. In other words, industrial concentration is more strongly linked than industrial diversity to employment change. The negative correlation between regional manufacturing concentration and diversity is apparent as well. All of the concentration variables increase in strength when diversity is omitted from the regression (except for Theil's entropy measure, which remains highly significant), as does the diversity variable when concentration is removed. Diversity is less likely to be found in regions with high levels of concentration in one or a few dominant manufacturing firms.

This experiment also provides reason to be cautious in assessing the empirical literature regarding the influence of industrial diversity. While most studies have found positive impacts 
Table 5. Reduced Regression Results, Omitting Concentration or Diversity.

\begin{tabular}{|c|c|c|c|c|}
\hline \multirow[b]{2}{*}{ Variable } & \multicolumn{2}{|c|}{ Include Diversity } & \multicolumn{2}{|c|}{ Concentration Only } \\
\hline & Coeff. & $\mathrm{p}$ Value & Coeff. & $\mathrm{p}$ Value \\
\hline \multicolumn{5}{|c|}{ Five-Firm Concentration Ratio } \\
\hline Concentration & $-29,760$ & $0.0013 * *$ & $-26,772$ & $<.0001 * *$ \\
\hline Diversity & 9,231 & 0.6276 & - & \\
\hline \multicolumn{5}{|c|}{ Herfindahl-Hirschman Index } \\
\hline Concentration & $-28,976$ & 0.2282 & $-40,126$ & $0.0133 *$ \\
\hline Diversity & $-13,353$ & 0.5308 & - & \\
\hline \multicolumn{5}{|l|}{ Rosenbluth Index } \\
\hline Concentration & $-184,853$ & $0.0004 * *$ & $-179,848$ & $<.0001 * *$ \\
\hline Diversity & 2,924 & 0.8641 & - & \\
\hline \multicolumn{5}{|l|}{ Theil's Entropy } \\
\hline Concentration & 9,004 & $<.0001 * *$ & 7,399 & $<.0001 * *$ \\
\hline Diversity & 29,831 & 0.0801 & - & \\
\hline \multicolumn{5}{|c|}{ Omit Concentration } \\
\hline Diversity & $-32,380$ & $0.0245 *$ & - & \\
\hline
\end{tabular}

* Significant at the $5 \%$ confidence level. $* *$ Significant at the $1 \%$ confidence level.

of diversity on a number of economic outcomes, the magnitude and statistical significance of these impacts varies widely across studies (Wagner 2000; Dissart 2003). To the author's knowledge, no prior studies consider diversity together with industry- or sector-specific concentration. Empirical analyses of industrial diversity may suffer from omitted variable bias in failing to include concentration.

\section{Concentration in Manufacturing Subsectors}

This portion of the study narrows the industrial units examined, performing separate regressions for each of the two-digit SIC subsectors that comprise the manufacturing sector (Table 6). The intent is to not to analyze particular industry subsectors, but to compare findings across the range of manufacturing activities for aggregations of establishments that are somewhat more internally homogeneous than an entire sector, and to investigate concentration calculated at a finer grain. The units of analysis remain MSAs and CMSAs, but for each subsector the set of regions is restricted to those with at least twelve firms in the industry in 1987 to ensure the 
meaningfulness of the concentration variables. A few of the subsectors have twelve or more firms only in a small number of metropolitan areas, so the regression estimations may not be very precise. For most subsectors in most regions, however, the restriction is not constraining.

The dependent variable in each regression is again the change in employment from 1987 to 1997. Concentration is measured for the particular 2-digit manufacturing subsector. Diversity is still calculated at the manufacturing sector level of aggregation, since the regional benefits of industrial diversity are theorized to arise from differences rather than similarities among economic activities. The control variables from the previous section are retained: the 1987 level of subsector employment accounts for varying industry size across regions, and dummy variables denote the Census Regions. Two additional controls recognize the increased complexity with greater industrial disaggregation. Manufacturing-wide industrial concentration is included in addition to subsectoral concentration, with the type of index or measure selected to match the subsector-specific concentration variable. Specialization at the subsector level is indicated by a location quotient calculated relative to the national manufacturing sector.

The center section of Table 7 displays the estimates for the regional industrial structure

Table 6. Two-digit SIC Manufacturing Subsectors and United States Totals.

\begin{tabular}{|c|c|c|c|c|c|}
\hline \multirow[b]{2}{*}{ SIC } & \multirow[b]{2}{*}{ Manufacturing Subsector } & \multicolumn{2}{|c|}{1987} & \multicolumn{2}{|c|}{1997} \\
\hline & & Establishments & Employment & Establishments & Employment \\
\hline 20 & Food and kindred products & 20,837 & $1,424,686$ & 21,223 & $1,539,682$ \\
\hline 21 & Tobacco products & 143 & 44,348 & 142 & 34,166 \\
\hline 22 & Textile mill products & 6,632 & 691,046 & 6,190 & 553,198 \\
\hline 23 & Apparel and other textile products & 22,767 & $1,073,364$ & 23,939 & 835,219 \\
\hline 24 & Lumber and wood products & 33,998 & 697,602 & 37,207 & 745,254 \\
\hline 25 & Furniture and fixtures & 11,659 & 505,284 & 12,222 & 514,504 \\
\hline 26 & Paper and allied products & 6,433 & 626,865 & 6,542 & 621,072 \\
\hline 27 & Printing and publishing & 61,918 & $1,500,624$ & 62,577 & $1,501,714$ \\
\hline 28 & Chemicals and allied products & 12,194 & 812,789 & 12,386 & 832,546 \\
\hline 29 & Petroleum and coal products & 2,300 & 122,285 & 2,144 & 107,829 \\
\hline 30 & Rubber and miscellaneous plastics products & 13,813 & 785,562 & 16,814 & $1,015,177$ \\
\hline 31 & Leather and leather products & 2,221 & 131,017 & 1,861 & 83,387 \\
\hline 32 & Stone, clay, and glass products & 16,716 & 543,510 & 16,570 & 500,828 \\
\hline 33 & Primary metal industries & 6,874 & 685,115 & 6,628 & 686,161 \\
\hline 34 & Fabricated metal products & 35,842 & $1,447,391$ & 38,691 & $1,537,591$ \\
\hline 35 & Industrial machinery and equipment & 53,011 & $1,917,039$ & 56,696 & $1,954,761$ \\
\hline 36 & Electronic and other electical equipment & 17,570 & $1,977,294$ & 17,398 & $1,528,348$ \\
\hline 37 & Transportation equipment & 10,300 & $1,823,573$ & 12,677 & $1,573,789$ \\
\hline 38 & Instruments and related products & 9,032 & 603,070 & 11,941 & 813,612 \\
\hline \multirow[t]{2}{*}{39} & Miscellaneous manufacturing industries & 17,031 & 387,809 & 18,471 & 399,391 \\
\hline & MANUFACTURING TOTAL & 371,018 & $19,002,692$ & 393,091 & $18,632,696$ \\
\hline
\end{tabular}

Source: County Business Patterns (United States Census Bureau, n.d.).

Note: Column sums do not equal totals due to omission of data from counties with fewer than 50 subsector employees. 
Table 7. Key Variable Results for Manufacturing Subsectors.

\begin{tabular}{|c|c|c|c|c|c|c|c|c|c|c|}
\hline Subsector & Obs. & $\mathrm{R}^{2}$ & $\begin{array}{r}\text { Regional } \\
\text { Subsector } \\
\text { Concentration } \\
\text { (Conc. Ratio) } \\
\end{array}$ & $\begin{array}{l}\text { Industrial Struct } \\
\text { Manufacturing } \\
\text { Diversity }\end{array}$ & $\begin{array}{l}\text { cture Variables } \\
\text { Manufacturing } \\
\text { Concentration } \\
\text { (Conc. Ratio) } \\
\end{array}$ & Specialization & \multicolumn{2}{|c|}{$\begin{array}{c}\text { Diversity Omitted } \\
\text { Subsector } \\
\text { Concentration }\end{array}$} & Concentra & $\begin{array}{l}\text { ation Omitted } \\
\text { Manufacturing } \\
\text { Diversity } \\
\end{array}$ \\
\hline 20 & 190 & 0.1888 & - & - & - & + & 0.1852 & - & 0.1848 & - \\
\hline 21 & 1 & n.a. & $\leftarrow--$ & ---- biase & sed ---- & $--\rightarrow$ & n.a. & biased & n.a. & biased \\
\hline 22 & 43 & 0.8605 & $-* *$ & - & + & - & 0.8604 & - ** & 0.8227 & + \\
\hline 23 & 112 & 0.3742 & + & - & + & - & 0.3689 & - & 0.3741 & - \\
\hline 24 & 208 & 0.2828 & $-\dagger$ & - & + & $-*$ & 0.2793 & - & 0.2729 & - \\
\hline 25 & 101 & 0.5542 & - & - & + & $+* *$ & 0.5533 & - & 0.5417 & - \\
\hline 26 & 69 & 0.5641 & $-* *$ & - & - & $+* *$ & 0.5639 & $-* *$ & 0.5072 & - \\
\hline 27 & 253 & 0.7233 & $-* *$ & - & + & + & 0.7228 & $-* *$ & 0.6498 & - \\
\hline 28 & 118 & 0.4612 & $-* *$ & - & - & + & 0.4608 & $-* *$ & 0.3927 & + \\
\hline 29 & 31 & 0.6011 & + & + & + & + & 0.5976 & + & 0.5994 & + \\
\hline 30 & 117 & 0.2423 & $-* *$ & - & + & - & 0.2413 & $-* *$ & 0.1528 & - \\
\hline 31 & 22 & 0.8803 & - & + & - & + & 0.8719 & - & 0.8708 & + \\
\hline 32 & 157 & 0.5617 & - & - & - & - & 0.5603 & - & 0.5581 & - \\
\hline 33 & 70 & 0.5779 & - & - & - & ++ & 0.5765 & - & 0.5771 & - \\
\hline 34 & 200 & 0.2580 & - ** & - & + & + & 0.2572 & $-* *$ & 0.2179 & + \\
\hline 35 & 225 & 0.3708 & $-* *$ & - & - & + & 0.3705 & $-* *$ & 0.3501 & + \\
\hline 36 & 115 & 0.1367 & - & - & + & + & 0.1345 & - & 0.1205 & - \\
\hline 37 & 110 & 0.8619 & + & + & - & $+*$ & 0.8619 & + & 0.8619 & + \\
\hline 38 & 84 & 0.6908 & $-* *$ & + & + & + & 0.6874 & $-* *$ & 0.6536 & + \\
\hline 39 & 131 & 0.7283 & - ** & -+ & - & -+ & 0.7215 & $-* *$ & 0.6882 & - \\
\hline
\end{tabular}

variables: manufacturing diversity, subsector concentration, manufacturing-wide concentration, and specialization. Concentration is measured using the five-firm concentration ratio. The signs and significance ranges are presented, but not the parameter estimates. These simplifications serve a dual purpose: they facilitate visual comparison across the series of regressions, and also minimize disclosure screening requirements. (The signs and significance ranges for the control variables are provided in Appendix Table 2; the implications are analogous to those discussed in the previous subsection.) Because fewer observations are involved in these regressions, probability values are noted at the ten percent as well as the five and one percent levels. The coefficients of determination $\left(\mathrm{R}^{2}\right)$ demonstrate that the degree to which the set of independent variables explain the regional variation in employment change fluctuates widely by subsector, as should be expected for exploratory regressions.

Clearly, the degree of regional concentration in the particular subsector is the most important of the four variables shown. Industrial concentration is a negative and significant influence on employment change in about half of the subsectors, and has uncertain (as opposed to clearly positive) effects in the other half. Several of the subsectors in which the concentration variable is only weakly related to employment change are those with fewer suitable metropolitan regions as observations, such as petroleum and coal (SIC 29), leather (SIC 31), and primary 
metals (SIC 33). The other industrial structure variables are far less prominent. Neither manufacturing-wide concentration nor manufacturing diversity is substantially associated with employment shifts at the manufacturing subsector level. Specialization has strong effects in only a few of the subsectors. These results hold when the other concentration measures are substituted for the concentration ratio (Appendix Tables 3-5).

The rightmost section of Table 7 displays the coefficients estimated when manufacturing diversity and subsector-specific concentration are alternately omitted from the regressions. The changes in statistical significance are for the most part negligible; for most of the two-digit manufacturing subsectors, employment performance is more closely associated with concentration than diversity when the structural characteristics are assessed separately as well as together. The coefficient of determination provides a helpful metric as well. With diversity removed, the $\mathrm{R}^{2}$ values decline only slightly, indicating little loss of association with variation in the dependent variable, but when subsector concentration is dropped from the equation the $\mathrm{R}^{2}$ values are reduced substantially in many of the industry subsectors. The evidence suggests that subsectoral concentration is more closely related to employment performance than is diversity.

\section{Concentration, Diversity, and Productivity in Three Manufacturing Industries}

The analyses presented so far indicate that concentration is a more important influence than diversity on employment change. This section presents a different approach, in order to assess a distinct facet of the relationship between regional industrial structure and economic performance. Instead of employment change, the outcome studied is productivity. Instead of looking at relatively large sectors of the economy, the units of analysis are establishments within three specific manufacturing industries. Instead of exploratory regressions, the model fully specifies the relationships between production, inputs, industrial structure, and regional characteristics based on economic theory. The methodology is outlined very briefly, and only partial estimation results are presented here; for more technical detail as well as the full estimation results, please see Drucker and Feser (2007) and Drucker (2007).

For each industry examined, a production function is estimated jointly with cost share equations derived from first-order conditions, with individual establishments forming the units of analysis. These cross-sectional production functions are specified in translog form, a general and 
flexible form that has been successfully applied to Census micro-level data (e.g., Nguyen and Reznek 1990; Feser 2001; Moretti 2004). The coefficients are estimated using iterated nonlinear seemingly unrelated regression to accommodate error correlations across equations. The establishment-level production function is

$$
\begin{aligned}
\ln Q= & \alpha_{0}+\sum_{i} \alpha_{i} \ln X_{i}+\frac{1}{2} \sum_{i} \sum_{j} \beta_{i j}\left(\ln X_{i} \ln X_{j}\right) \\
& +\sum_{k} \gamma_{k} \ln Z_{k}+\sum_{i} \sum_{k} \mathrm{I}(i, k) \lambda_{i k} \ln X_{i} \ln Z_{k}+\sum_{k} \sum_{l} \mathrm{I}(k, l) \lambda_{k l} \ln Z_{k} \ln Z_{l}
\end{aligned}
$$

where $Q$ is establishment output, $X$ represents four conventional inputs (capital, labor, energy, and materials) that are indexed by the subscripts $i$ and $j, Z$ is a vector of regional characteristics including structural variables that are indexed by $k$ and $l$, and I represents an indicator function that permits selective inclusion of interaction terms. Additive disturbance terms appended to the production function (not shown) and cost share equations are assumed to follow a multivariate standard normal distribution.

The five-firm concentration ratio measure (or Herfindahl-Hirschman index measure or Rosenbluth index measure) of industrial concentration and the Herfindahl-Hirschman index of diversity (now measured economy-wide) enter the model as regional characteristics. Additional regional traits include five agglomeration economy variables, indicating potential regional advantages arising from knowledge spillovers among similar industries and local pools of specialized labor, industry-specific suppliers, and business services, along with several control variables. $^{7}$ The input, output, and cost share variables are calculated from the LRD. (Appendix Table 6 lists the full set of variables; Appendix 2 provides construction details.) All non-dummy variables are mean-centered to enter the production function. Variables not measured as percentages or ratios are transformed with natural logarithms; the coefficient estimates are interpreted as elasticities at the sample means.

Three manufacturing industries are examined: plastics and rubber (SIC 30), metalworking machinery (SIC 354), and measuring and controlling devices (SIC 382). All establishments nationwide are included save those located in Alaska or Hawaii and the very smallest plants, most often employing five or fewer workers, that are not required to provide full information concerning production inputs. Each industry has enough establishments spread

\footnotetext{
${ }^{7}$ Although measures of the change over the past twenty years in industrial concentration and manufacturing diversity were also included as controls, these variables yielded negligibly small effects on production outcomes.
} 
across a sufficient number of regions to present adequate variation in regional structural characteristics and to support the relatively complex translog estimation system. The industries are relatively homogeneous in production technology, sustaining the conceptual validity of production function parameters estimated across plants, and together include both technologyintensive and traditional manufacturing practices. The production function system is estimated for each industry for 1992, 1997, and 2002. Should the results prove similar, multiple crosssections impart increased confidence in the findings.

This complex model, estimated for nine separate cross-sections, yields a tremendous volume of information. Only the subset of results that pertains most directly to the question at hand - the influence of regional industrial structure — are presented here. To start, the Pearson pairwise correlations between industrial concentration and economy-wide industrial diversity are tabulated in Table 8. All are positive (recall that the Herfindahl-Hirschman index gauges diversity inversely), and due to the large number of observations, all are highly significant. Nevertheless, with industrial concentration considered for specific industries and diversity measured across the entire economy, the overlap is much less than in the previous analyses, not large enough to interfere with the regression estimations.

The coefficients of industrial concentration and diversity estimated from the production function model are presented in Table 9. Again, because the study samples are better characterized as a census than a representative sample, statistical significance is a useful gauge of relationship strength but does not carry inferences for larger populations. The strength of the influence on production, as indicated by the parameter significance, varies across the three industries examined, from the least often significant in the rubber and plastics industry (SIC 30) to mostly highly significant for metalworking machinery plants (SIC 354). The coefficient significance is largely consistent over time in the rubber and plastics and metalworking machinery industries, but declines over time in the measuring and controlling devices industry, the most technology-intensive and volatile of the three study industries. Comparing concentration with diversity, the strength of influence on production is comparable for each cross-section if the measure of concentration is the concentration ratio or Herfindahl-Hirschman index. When measured with the Rosenbluth index, however, concentration is much more strongly linked to productivity than is diversity. Although the correlations between diversity and concentration as indicated by the Rosenbluth index measure are similar to those with the 
concentration ratio (Table 8), the overlap that does exist may coincide more closely with the influence on production.

The coefficients in Table 9 are difficult to compare because of the contrast in the variables' methods of construction as well as differing sample properties. Table 10 lists the estimated effect of an increase of one standard deviation in each measure of concentration and diversity, reported as the percent change in output produced, calculated at the sample means of each of the independent variables. For example, a standard deviation rise in the concentration ratio is associated with a decline in output of 3.8 percent in the metalworking machinery industry (SIC 354) in 2002. The significance notations are replicated from Table 9 for convenience.

Table 8. Correlations between Industrial Concentration and Diversity.

\begin{tabular}{rrrrrr}
\hline \multirow{2}{*}{ Industry } & Year & Obs. & $\begin{array}{r}\text { Concentration } \\
\text { Ratio }\end{array}$ & $\begin{array}{r}\text { Herfindahl- } \\
\text { Hirschman Index }\end{array}$ & $\begin{array}{r}\text { Rosenbluth } \\
\text { Index }\end{array}$ \\
\hline \multirow{3}{*}{30} & 1992 & 6,747 & 0.4073 & 0.2899 & 0.3907 \\
& 1997 & 8,000 & 0.4784 & 0.3191 & 0.4568 \\
& 2002 & 6,546 & 0.4782 & 0.4318 & 0.4777 \\
354 & 2002 & 5,189 & 0.1522 & 0.1246 & 0.2638 \\
& 1997 & 5,490 & 0.1656 & 0.1014 & 0.2901 \\
382 & 1902 & 4,161 & 0.2828 & 0.1983 & 0.3219 \\
& 1992 & 1,384 & 0.5120 & 0.4468 & 0.3959 \\
& 2002 & 1,540 & 0.3475 & 0.3100 & 0.3825 \\
\hline
\end{tabular}

Note: All correlations significant at the $0.01 \%$ confidence level.

Table 9. Estimated Coefficients for Industrial Concentration and Diversity.

\begin{tabular}{|c|c|c|c|c|c|c|c|}
\hline Industry & Year & $\begin{array}{r}\text { Concentration } \\
(\text { Conc. Ratio) }\end{array}$ & Diversity & $\begin{array}{r}\text { Concentration } \\
\text { (Herf.-Hirsch.) } \\
\end{array}$ & Diversity & $\begin{array}{r}\text { Concentration } \\
\text { (Rosenbluth) }\end{array}$ & Diversity \\
\hline \multirow{3}{*}{30} & 1992 & -0.0447 & 1.6090 & -0.1616 & 1.8020 & $-0.9101 * *$ & $2.3999 *$ \\
\hline & 1997 & -0.0510 & $-1.4940+$ & -0.0457 & $-1.6628^{*}$ & $-0.5765 * *$ & -1.1033 \\
\hline & 2002 & $-0.0653+$ & 0.5539 & $-0.4631 * *$ & 0.7381 & $-1.0107 * *$ & 0.9604 \\
\hline \multirow{3}{*}{354} & 1992 & $-0.0875 *$ & $-3.1462 *$ & -0.1121 & $-2.9978 *$ & -0.2563 & $-2.5278+$ \\
\hline & 1997 & $-0.2001 * *$ & $-4.0410 * *$ & $-0.1830 *$ & $-3.5689 * *$ & $-0.6614 * *$ & -1.5886 \\
\hline & 2002 & $-0.1900 * *$ & $-4.0307 * *$ & $-0.2661 * *$ & $-3.8297 * *$ & $-0.7175 * *$ & $-2.3981+$ \\
\hline \multirow{3}{*}{382} & 1992 & $-0.3532 *$ & $-22.1439 * *$ & $-0.6369 *$ & $-21.9872 * *$ & $-2.0502 * *$ & $-15.1614+$ \\
\hline & 1997 & $-0.2499+$ & $-9.5446+$ & -0.1969 & -7.8995 & $-1.8161 * *$ & -2.7662 \\
\hline & 2002 & 0.1184 & -5.8544 & $0.5532 *$ & -9.5062 & 0.0582 & -11.0787 \\
\hline
\end{tabular}

$\dagger$ Significant at the $10 \%$ confidence level. $*$ Significant at the $5 \%$ confidence level. $* *$ Significant at the $1 \%$ confidence level. 
Table 10. Marginal Impacts of Industrial Concentration and Diversity.

\begin{tabular}{cccccccc}
\hline Industry & Year & $\begin{array}{c}\text { Concentration } \\
\text { (Conc. Ratio) }\end{array}$ & Diversity & $\begin{array}{c}\text { Concentration } \\
\text { (Herf.-Hirsch.) }\end{array}$ & \multicolumn{3}{c}{$\begin{array}{c}\text { Concentration } \\
\text { Diversity }\end{array}$} \\
\hline \multirow{6}{*}{30} & 1992 & -0.85 & 0.60 & -1.17 & 0.67 & $-3.87 * *$ & $0.89 *$ \\
& 1997 & -0.99 & $-0.65+$ & -0.35 & $-0.72 *$ & $-2.60 * *$ & -0.48 \\
& 2002 & $-1.30+$ & 0.30 & $-3.48 * *$ & 0.40 & $-5.72 * *$ & 0.53 \\
& 1992 & $-1.72 *$ & $-1.21 *$ & -0.92 & $-1.15 *$ & -1.23 & $-0.97 \dagger$ \\
354 & 1997 & $-4.18 * *$ & $-1.43 * *$ & $-1.75 *$ & $-1.27 * *$ & $-3.73 * *$ & -0.56 \\
& 2002 & $-3.82 * *$ & $-1.91 * *$ & $-2.69 * *$ & $-1.81 * *$ & $-5.14 * *$ & $-1.14 \dagger$ \\
& 1992 & $-6.49 *$ & $-4.27 * *$ & $-9.51 *$ & $-4.24 * *$ & $-13.74 * *$ & $-2.92 \dagger$ \\
382 & 1997 & $-3.79+$ & $-2.01+$ & -2.38 & -1.66 & $-10.70 * *$ & -0.58 \\
& 2002 & 1.65 & -1.39 & $6.81 *$ & -2.26 & 0.37 & -2.64 \\
\hline
\end{tabular}

+ Significant at the $10 \%$ confidence level. $*$ Significant at the $5 \%$ confidence level. $* *$ Significant at the $1 \%$ confidence level.

Table 10 makes it clear that the negative marginal impacts are greater for industrial concentration than diversity. A standard deviation increase in industrial concentration is associated with productivity decreases ranging from about 50 percent more to many times greater than those associated with diversity. Again, the greatest disparity occurs with the Rosenbluth index measure of concentration, for which the coefficients are much more commonly significant and represent marginal impacts as large as 10-20 times greater than for diversity. Furthermore, a standard deviation change is not equally probable (or improbable) for the two structural characteristics. While both concentration and diversity tend to endure over time, there not only is greater variation across regions in concentration than diversity, but industrial concentration is measured with respect to a smaller group of firms. A substantial shift in industry-specific concentration can be accomplished with a much smaller change in the regional economic landscape than would be necessary to alter diversity across the entire economy. Nevertheless, overall, the substantial magnitudes for both concentration and diversity emphasize the importance of the influence that regional industrial structure exerts on establishment productivity.

Finally, as in the preceding analyses, it is interesting to see what happens if only one of the regional industrial structure variables is included in the production model. Table 11 displays the marginal impacts of a standard deviation increase in concentration or diversity estimated with the other structural variable omitted (Appendix Table 7 provides the coefficients). Comparing between Tables 10 and 11, for the rubber and plastics plants (SIC 30) most of the changes are 
Table 11. Marginal Impacts, Omitting Concentration or Diversity.

\begin{tabular}{ccccc|c}
\hline Industry & Year & $\begin{array}{c}\text { Concentration } \\
\text { (Conc. Ratio) }\end{array}$ & $\begin{array}{l}\text { Diversity Omitted } \\
\text { Concentration } \\
\text { (Herf.-Hirsch.) }\end{array}$ & $\begin{array}{c}\text { Concentration } \\
\text { (Rosenbluth) }\end{array}$ & $\begin{array}{c}\text { Concentration } \\
\text { Omitted } \\
\text { Diversity }\end{array}$ \\
\hline \multirow{3}{*}{30} & 1992 & -0.66 & -0.96 & $-3.07 * *$ & $0.58^{*}$ \\
& 1997 & -0.95 & -0.44 & $-2.62 * *$ & $-0.78^{*}$ \\
& 2002 & $-1.34+$ & $-3.49 * *$ & $-5.56 * *$ & -0.31 \\
354 & 1992 & $-1.85^{*}$ & -1.18 & $-1.73+$ & $-1.17 *$ \\
& 1997 & $-4.11 * *$ & $-1.99 * *$ & $-3.83 * *$ & $-1.26^{* *}$ \\
& 2002 & $-4.17^{* *}$ & $-3.14 * *$ & $-5.62 * *$ & $-1.41^{*}$ \\
382 & 1992 & $-8.56^{* *}$ & $-14.31^{* *}$ & $-18.37 * *$ & $-5.36^{* *}$ \\
& 1997 & $-5.28 * *$ & $-4.32 *$ & $-11.68 * *$ & $-2.28^{*}$ \\
& 2002 & 2.55 & $7.30^{*}$ & 0.85 & $-2.76+$ \\
\hline
\end{tabular}

+ Significant at the $10 \%$ confidence level. * Significant at the 5\% confidence level. $* *$ Significant at the $1 \%$ confidence level.

relatively small, with decreases in impact as frequent as increases. The changes are also quite small in the metalworking machinery industry (SIC 354), though nearly all of the estimates do increase. For the measuring and controlling devices industry (SIC 382), however, the estimated marginal impacts of both concentration and diversity increase substantially, and often gain in significance, when the other structural variable is removed. In other words, there is no discernible overlap between industry-specific concentration and economy-wide diversity in terms of the influence on productivity in rubber and plastics plants, and only a small confluence for metalworking machinery plants, but the two variables coincide in their impacts to a substantial degree for establishments that manufacture measuring and controlling devices. While industrial concentration remains the more powerful influence on plant productivity in each crosssection, it is not unreasonable to extrapolate that aspects of the production process or interfirm relationships that are particular to specific industries may mediate the effects of regional industrial structure on productivity, making industry-specific analyses necessary. 


\section{Summary and Implications}

Research into industrial structure and its effects on economic performance has a long history in multiple academic fields. Industrial diversity, along with industry scale and average plant size, has been evaluated in many empirical studies conducted for regions as well as nations. Yet the topic of industrial concentration at the regional scale has claimed little systematic analytical effort. This paper compares the economic influence of regional industrial concentration with that of industrial diversity for United States manufacturing businesses using confidential establishment-level data. Operationalizing concentration with several constructs and at multiple levels of industrial aggregation helps reveal the properties of an understudied aspect of regional industrial structure. By evaluating the impacts of concentration in contrast to diversity, the paper expands the consideration of regional concentration and begins to place the subject in an appropriate empirical context.

Examining the manufacturing sector as a whole, concentration at the regional level evidences a substantial negative impact on employment change. Measured during the decade from 1987 to 1997 , a time of national decline in manufacturing employment, regional concentration in manufacturing increases the expected job loss substantially. This result is robust (to within an order of magnitude) for four different measures of industrial concentration. The estimates for industrial diversity are much weaker and less stable across the concentration variable specifications. This may be partially explained by overlap between the measures and in the empirical incidence of diversity and concentration, yet overall the indication is that manufacturing concentration is much more strongly linked to employment loss than is lack of diversity.

The findings are similar for the industrial subsectors that constitute the manufacturing sector. Subsector concentration generates a greater influence on employment than does either diversity or concentration measured across the whole manufacturing sector. For all but one of the nineteen subsectors, neither the diversity nor manufacturing sector concentration variables demonstrate significant associations with employment changes over time. There is much less indication that concentration within subsectors overlaps with diversity than was the case for manufacturing-wide concentration. 
Turning to the individual industry level, production estimations carried out for three industries and for three years reveal that both industry-specific concentration and industrial diversity have substantial associations with plant-level productivity. The strength of the relationships and the relative magnitudes of the influences vary by industry, with plastics and rubber manufacturing plants the least affected and measuring and controlling device manufacturers the most affected. The degree to which the concentration and diversity variables coincide in their impacts also differs by industry, with the greatest overlap occurring in the measuring and controlling devices industry. The estimates using the Rosenbluth index, which adds extra weight to the small end of the size distribution, suggest a much greater influence of concentration than do the other measures tested, perhaps reflecting the importance of the role of small businesses in improving industrial productivity. Overall, across all of the cross-sections and concentration measures, taking the sample range and variation of the measures into account, the expected marginal impacts on production are greater for industrial concentration than for diversity.

For economic analysts and researchers of industrial organization, industrial concentration provides a new avenue for investigating regional industrial structure. The empirical analyses in this study confirm the importance of regional industrial concentration as an aspect of industrial structure that is influential both to sectoral employment change and to plant productivity. The mechanisms by which this influence is imposed, however, are not clearly understood. Numerous possible pathways have been described, several of which are similar to those hypothesized and tested for industrial diversity, but more research is needed to identify and clarify the ways in which industrial structure impacts interfirm relationships and affects economic outcomes of interest. More generally, our understanding of regional industrial concentration would benefit from additional examination at different scales of aggregation, in an assortment of regions or across nations, and for a variety of industries, including growing sectors of the economy such as services.

The primary finding - that economic performance within manufacturing is affected as much, and usually more, by concentration than diversity - is reached with two different methodologies applied to several industrial scales and two relevant outcomes, evaluated for regions across the United States. This has implications for those interested in the effects of regional industrial structure on local and regional economic performance. The informational 
requirements make nationwide analyses of regional industrial structure such as this one difficult to perform. The local level is where regional industrial structure in general, and regional industrial concentration in particular, is most able to be measured (or approximated) and evaluated, using data available locally or collected for the purpose. Yet economic analysts and local economic development practitioners typically do not investigate or even think about the notion of concentration within regional industries. And, in comparison with diversity, industryspecific concentration may be the more important regional structural feature to understand, investigate locally, and factor into policy discussions. In particular, programs seeking to make progress in the short run toward the goals of adaptability and flexibility, very much in vogue during the current recession, need to account for the limitations and constraints imposed by industrial concentration upon the performance of local enterprises. In the long run, economic development planners may wish to consider possibilities for policies that aim to counter the negative effects of concentration while retaining the possible benefits of anchor institutions. 
Acs, Z. J., and C. Armington. 2004. Employment growth and entrepreneurial activity in cities. Regional Studies, 38 (8): 911-927.

Acs, Z. J., and D. B. Audretsch. 1990. Innovation and Small Firms. Cambridge, Massachusetts: MIT Press.

Acs, Z. J., R. Morck, and B. Yeung. 1999. Productivity growth and firm size distribution. In Z. J. Acs, B. Carlsson, and C. Karlsson (eds.), Entrepreneurship, Small and Medium-Sized Enterprises and the Macroeconomy: 367-396. Cambridge, United Kingdom: Cambridge University Press.

Agrawal, A., and I. Cockburn. 2003. The anchor tenant hypothesis: exploring the role of large, local, R\&D-intensive firms in regional innovation systems. International Journal of Industrial Organization, 21: 1227-1253.

Amato, L. 1995. The choice of structure measure in industrial economics. Quarterly Journal of Business and Economics, 34 (2): 39-52.

Armington, C., and Z. J. Acs. 2002. The determinants of regional variation in new firm formation. Regional Studies, 36 (1): 33-45.

Attaran, M., and M. M. Saghafi. 1988. Concentration trends and profitability in the US manufacturing sector: 1970-84. Applied Economics, 20 (11): 1497-1510.

Audretsch, D. 2001a. Research issues related to structure, competition, and performance of small technology-based firms. Small Business Economics, 16 (1): 37-51.

Audretsch, D. B. 2001b. Research issues relating to structure, competition, and performance of small technology-based firms. Small Business Economics, 16 (1): 37-51.

Axtell, R. L. 2001. Zipf distribution of U.S. firm sizes. Science, 293 (5536): 1818-1820.

Bergman, E. M. 2002. Sustainability of Clusters: Ten Dos and Don'ts. Presented at the FortyFirst Western Regional Science Association Annual Meeting: Monterey, California.

Booth, D. E. 1986. Long waves and uneven regional growth. Southern Economic Journal, 53 (2): 448-460.

Bottazzi, G., and A. Secchi. 2003. Why are distributions of firm growth rates tent-shaped? Economics Letters, 80 (3): 415-420.

Brewer, H. L. 1985. Measures of diversification: predictors of regional economic instability. Journal of Regional Science, 25 (3): 463-470.

Carlino, G. A. 1980. Agglomeration: New York and Pittsburgh reconsidered. Urban Studies, 17 (3): 343-351.

Carlino, G. A. 1987. Comparisons of agglomeration: or what Chinitz really said: a reply. Urban Studies, 24 (1): 75-76.

Carree, M., and R. Thurik. 1999. Industrial structure and economic growth. In D. Audretsch, and R. Thurik (eds.), Innovation, Industry Evolution, and Employment: 86-110. Cambridge, UK: Cambridge University Press.

Caves, R. E. 1998. Industrial organization and new findings on the turnover and mobility of firms. Journal of Economic Literature, 36 (4): 1947-1982.

Caves, R. E., and D. R. Barton. 1990. Efficiency in U.S. manufacturing industries. Cambridge, Massachusetts: MIT Press.

Chinitz, B. 1961. Contrasts in agglomeration: New York and Pittsburgh. The American Economic Review, 51 (2): 279-289. 
Christopherson, S., and J. Clark. 2007. Remaking Regional Economies: Power, Labor, and Firm Strategies in the Knowledge Economy. London, United Kingdom: Routledge.

Cohen, W. M., and R. C. Levin. 1989. Empirical studies of innovation and market structure. In R. Schmalensee, and R. D. Willig (eds.), Handbook of Industrial Organization: 10591107. Amsterdam, Netherlands: Elsevier.

Cohen, W. M., R. R. Nelson, and J. P. Walsh. 2002. Links and impacts: the influence of public research on industrial R\&D. Management Science, 48 (1): 1-23.

Collins, N. R., and L. E. Preston. 1961. The size structure of the largest industrial firms, 19091958. The American Economic Review, 51 (5): 986-1011.

Combes, P.-P. 2000. Economic structure and local growth: France, 1984-1993. Journal of Urban Economics, 47 (3): 329-355.

Conroy, M. E. 1975. Regional Economic Diversification. New York, New York: Praeger Publishers.

Davies, S. W., and P. A. Geroski. 1997. Changes in concentration, turbulence, and the dynamics of market shares. The Review of Economics and Statistics, 79 (3): 383-391.

Desmet, K., and M. Fafchamps. 2005. Changes in the spatial concentration of employment across US counties: a sectoral analysis 1972-2000. Journal of Economic Geography, 5 (3): 261-284.

Dissart, J. C. 2003. Regional economic diversity and regional economic stability: research results and agenda. International Regional Science Review, 26 (4): 423-446.

Drucker, J. 2007. Regional dominance and industrial success: a productivity-based analysis. Doctoral Dissertation, Department of City and Regional Planning, University of North Carolina: Chapel Hill, North Carolina.

Drucker, J. 2009. Trends in regional industrial concentration in the United States. Working Paper CES-WP-09-06: Center for Economic Studies, United States Census Bureau. Available at http://www.ces.census.gov/index.php/ces/discussion_papers?detail_key=101855 (accessed April 15, 2009).

Drucker, J., and E. J. Feser. 2007. Regional industrial dominance, agglomeration economies, and manufacturing plant productivity. Working Paper CES-WP-07-31: Center for Economic Studies, United States Census Bureau. Available at http://www.ces.census.gov/index.php/ces/discussion_papers?detail_key=101804 (accessed January 13, 2008).

Duranton, G., and D. Puga. 2001. Nursery cities: urban diversity, process innovation, and the life cycle of products. The American Economic Review, 91 (5): 1454-1477.

Enright, M. 1995a. Organization and coordination in geographically concentrated industries. In N. R. Lamoreaux, and D. M. G. Raff (eds.), Coordination and Information: Historical Perspectives on the Organization of Enterprise: 103-146. Chicago: University of Chicago Press.

Enright, M. J. 1995b. Organization and coordination in geographically concentrated industries. In N. R. Lamoreau, and D. M. G. Raff (eds.), Coordination and Information: Historical Perspectives on the Organization of Enterprise: 103-146. Chicago, Illinois: University of Chicago Press.

Essletzbichler, J., and D. L. Rigby. 2002. The impact of industry mix, technological change, selection, and plant entry and exit on metropolitan labor productivity in the United States. Urban Geography, 23 (3): 279-298. 
Evans, A. W. 1986. Comparisons of agglomeration: or what Chinitz really said. Urban Studies, 23 (5): 387-389.

Feldman, M. P. 2003. The locational dynamics of the US biotech industry: knowledge externalities and the anchor hypothesis. Industry and Innovation, 10 (3): 311-328.

Feldman, M. P., and D. B. Audretsch. 1999. Innovation in cities: science-based diversity, specialization, and localized competition. European Economic Review, 43 (2): 409-429.

Feser, E. J. 2001. A flexible test for agglomeration economies in two US manufacturing industries. Regional Science and Urban Economics, 31 (1): 1-19.

Frenken, K., F. G. van Oort, and T. Verburg. 2007. Related variety, unrelated variety and regional economic growth. Regional Studies, 41 (5): 685-697.

Friedman, J. J. 1995. The effects of industrial structure and resources under the distribution of fast-growing small firms among US urbanised areas. Urban Studies, 32 (6): 863-884.

Gans, J. S., and J. Quiggin. 2003. A technological and organisational explanation for the size distribution of firms. Small Business Economics, 21 (3): 243-256.

Gerking, S. 1994. Measuring productivity growth in U.S. regions: a survey. International Regional Science Review, 16 (1-2): 155-185.

Glaeser, E. L., H. D. Kallal, J. A. Scheinkman, and A. Schleifer. 1992. Growth in cities. Journal of Political Economy, 100 (6): 1126-1152.

Glaeser, E. L., and W. R. Kerr. 2008. Local industrial conditions and entrepreneurship: how much of the spatial distribution can we explain? Working Paper 09-055: Harvard Business School.

Golan, A., G. Judge, and J. M. Perloff. 1996. Estimating the size distribution of firms using government summary statistics. The Journal of Industrial Economics, 44 (1): 69-80.

Gopinath, M., D. Pick, and Y. Li. 2004. An empirical analysis of productivity growth and industrial concentration in US manufacturing. Applied Economics, 36 (1): 1-17.

Gordon, I. R., and P. McCann. 2000. Industrial clusters: Complexes, agglomeration and/or social networks? Urban Studies, 37 (3): 513-32.

Gort, M., and N. Sung. 1999. Competition and productivity growth: the case of the U.S. telephone industry. Economic Inquiry, 37 (4): 678-691.

Grabher, G. 1993. The weakness of strong ties: the lock-in of regional development in the Ruhr area. Ch.12. In G. Grabher (ed.), The Embedded Firm: On the Socio-Economics of Industrial Networks. London, United Kingdom: Routledge.

Hanson, G. H. 2001. Scale economies and the geographic concentration of industry. Journal of Economic Geography, 1 (3): 255-276.

Harrison, B., M. R. Kelley, and J. Gant. 1996. Innovative firm behavior and local milieu: exploring the intersection of agglomeration, firm effects, and technological change. Economic Geography, 72 (3): 233-258.

Hay, D. A., and D. J. Morris. 1991. Industrial Economics and Organization: Theory and Evidence. Oxford, United Kingdom: Oxford University Press.

Helmsing, A. H. J. B. 2001. Externalities, learning and governance: New perspectives on local economic development. Development and Change, 32: 277-308.

Henderson, J. V. 1997. Externalities and industrial development. Journal of Urban Economics, 42 (3): 449-470.

Henderson, J. V. 2003. Marshall's scale economies. Journal of Urban Economics, 53 (1): 128. 
Henderson, J. V., A. Kuncoro, and M. A. Turner. 1995. Industrial development in cities. Journal of Political Economy, 103 (5): 1067-1090.

Henderson, J. V., Z. Shalizi, and A. J. Venables. 2001. Geography and development. Journal of Economic Geography, 1 (1): 81-105.

Holl, A. 2004a. Transport infrastructure, agglomeration economies, and firm birth: empirical evidence from Portugal. Journal of Regional Science, 44 (4): 693-712.

Holl, A. 2004b. Start-ups and relocations: manufacturing plant location in Portugal. Papers in Regional Science, 83 (4): 649-668.

Ijiri, Y., and H. A. Simon. 1977. Skew Distributions and the Sizes of Business Firms. Amsterdam, Netherlands: North-Holland Publishing.

Izraeli, O., and K. J. Murphy. 2003. The effect of industrial diversity on state unemployment rate and per capita income. Annals of Regional Science, 37 (1): 1-14.

Jacobs, J. 1969. The Economy of Cities. New York, New York: Random House.

Kambhampati, U. S., and P. McCann. 2007. Regional performance and characteristics of Indian manufacturing industry. Regional Studies, 41 (3): 281-294.

Koo, J. 2005. Knowledge-based industry clusters: evidenced by geographical patterns of patents in manufacturing. Urban Studies, 42 (9): 1487-1505.

Lall, S. V., and S. Chakravorty. 2005. Industrial location and spatial inequality: theory and evidence from India. Review of Development Economics, 9 (1): 47-68.

Lee, B. S., K. Sosin, and S. H. Hong. 2005. Sectoral manufacturing productivity growth in Korean regions. Urban Studies, 42 (7): 1201-1219.

Loveridge, S., and D. Nizalov. 2007. Operationalizing the entrepreneurial pipeline theory: an empirical assessment of the optimal size distribution of local firms. Economic Development Quarterly, 21 (3): 244-262.

Malecki, E. J. 1994. Entrepreneurship in regional and local development. International Regional Science Review, 16 (1-2): 119-153.

Malizia, E. E., and S. Ke. 1993. The influence of economic diversity on unemployment and stability. Journal of Regional Science, 33 (2): 221-235.

Malmberg, A., and P. Maskell. 2002. The elusive concept of localization economies: towards a knowledge-based theory of spatial clustering. Environment and Planning A, 34 (3): 429449.

Marshall, A. [1890] 1910. Principles of Economics. 6th Ed. London, United Kingdom: MacMillan.

Mason, C. M. 1991. Spatial variations in enterprise: The geography of new firm formation. In R. Burrows (ed.), Deciphering the Enterprise Culture: Entrepreneurship, Petty Capitalism, and the Restructuring of Britain: 74-107. London: Routledge.

McGuckin, R. H. 1990. Longitudinal Economic Data at the Census Bureau: A New Database Yields Fresh Insights On Some Old Issues. Working Paper CES-WP-90-1. Available at http://www.ces.census.gov/index.php/ces/1.00/cespapers?down_key=100131 (accessed September 29, 2007).

Mizuno, K., F. Mizutani, and N. Nakayama. 2006. Industrial diversity and metropolitan unemployment rate. Annals of Regional Science, 40 (1): 157-172.

Moomaw, R. L. 1986. Have changes in localization economies been responsible for declining productivity advantages in large cities? Journal of Regional Science, 26 (1): 193-2.

Moretti, E. 2004. Workers' education, spillovers, and productivity: evidence from plant-level production functions. The American Economic Review, 94 (3): 656-690. 
Mukkala, K. 2004. Agglomeration economies in the Finnish manufacturing sector. Applied Economics, 36 (21): 2419-2427.

Needham, D. 1978. The Economics of Industrial Structure, Conduct, and Performance. New York, New York: St. Martin's Press.

Nelson, R. R., and S. G. Winter. 1982. An Evolutionary Theory of Economic Change. Cambridge, MA: Harvard University Press.

Nguyen, S. V., and A. P. Reznek. 1990. Returns to scale in small and large U.S. manufacturing establishments. Working Paper CES-WP-90-11: Center for Economic Studies, United States Census Bureau. Available at http://www.ces.census.gov/index.php/ces/1.00/cespapers?down_key=100133 (accessed September 29, 2007).

Norton, R. D. 1992. Agglomeration and competitiveness: from Marshall to Chinitz. Urban Studies, 29 (2): 155-170.

Porter, M. E. 1990. The Competitive Advantage of Nations. New York, New York: MacMillan.

Porter, M. E. 1998. Clusters and the new economics of competition. Harvard Business Review, (November/December): 77-90.

Powell, T. C. 2003. Varieties of competitive parity. Strategic Management Journal, 24 (1): 61-86.

Powell, T. C., and C. J. Lloyd. 2005. Toward a general theory of competitive dominance: comments and extensions on Powell (2003). Strategic Management Journal, 26 (4): 385-394.

Pryor, F. L. 2001. New trends in U.S. industrial concentration. Review of Industrial Organization, 18 (3): 301-326.

Quigley, J. M. 1998. Urban diversity and economic growth. Journal of Economic Perspectives, $12(2): 127-138$.

Rantisi, N. M. 2002. The competitive foundations of localized learning and innovation: the case of the women's garment production in New York City. Economic Geography, 78 (4): 441-462.

Rosenthal, S. S., and W. S. Strange. 2004. Evidence on the Nature and Sources of Agglomeration Economies. In J. V. Henderson, and J.-F. Thisse (eds.), Handbook of Urban and Regional Economics, Vol. 4: 2119-2171. Amsterdam, Netherlands: Elsevier.

Saxenian, A. 1994a. Regional Advantage: Culture and Competition in Silicon Valley and Route 128. Cambridge, MA: Harvard University Press.

Saxenian, A. 1994b. Regional Advantage: Culture and Competition in Silicon Valley and Route 128. Cambridge, Massachusetts: Harvard University Press.

Scherer, F. M. 1980. Industrial Market Structure and Economic Performance. 2nd Edition Ed. Boston: Houghton-Mifflin.

Schmalensee, R. 1989. Inter-industry studies of structure and performance. In R. Schmalensee, and R. D. Willig (eds.), Handbook of Industrial Organization: 951-1009. Amsterdam, Netherlands: Elsevier.

Scott, A. J. 1986. Industrial Organization and Location: Division of Labor, the Firm, and Spatial Process. Economic Geography, 62: 215-231.

Scott, A. J. 1988a. Metropolis: From the Division of Labor to Urban Form. Berkeley, CA: University of California Press. 
Scott, A. J. 1988b. New Industrial Spaces: Flexible Production Organization and Regional Development in North America and Western Europe. London, United Kingdom: Pion Limited.

Scott, A. J., and E. C. Kwok. 1989. Inter-firm subcontracting and location agglomeration: A case study of the printed circuits industry of southern California. Regional Studies, 23 (5): 405-416.

Shearmur, R. G., and M. Polese. 2007. Do local factors explain local employment growth? Evidence from Canada, 1971-2001. Regional Studies, 41 (4): 453-471.

Stanley, M. H. R., S. V. Buldyrev, S. Havlin, R. N. Mantegna, M. A. Salinger, and H. E. Stanley. 1995. Zipf plots and the size distribution of firms. Economics Letters, 49 (4): 453-457.

Sutton, J. 1997. Gibrat's legacy. Journal of Economic Literature, 35 (1): 40-59.

United States Census Bureau. 2002. Metropolitan Areas and Components, 1999. Available at http://www.census.gov/population/estimates/metro-city/99mfips.txt (accessed September 29, 2007).

United States Department of Agriculture. 2003. Measuring Rurality: Commuting Zones and Labor Market Areas. Available at http://www.ers.usda.gov/briefing/rurality/lmacz (accessed September 29, 2007).

Vossen, R. W. 1999. Market power, industrial concentration and innovative activity. Review of Industrial Organization, 15 (4): 367-378.

Wagner, J. E. 2000. Regional economic diversity: action, concept, or state of confusion. Journal of Regional Analysis and Policy, 30 (2): 1-22.

Watts, H. D., A. M. Wood, and P. Wardle. 2003. 'Making friends or making things?': interfirm transactions in the Sheffield metal-working cluster. Urban Studies, 40 (3): 615-630. 
APPENDIX 1: Tables.

Appendix Table 1. Manufacturing Concentration and Diversity: Descriptive Statistics, 1987.

\begin{tabular}{lrr}
\hline Measure & Mean & Std. Dev. \\
\hline Five-Firm Concentration Ratio & 0.3940 & 0.1716 \\
Herfindahl-Hirschman Index & 0.0680 & 0.0699 \\
Theil's Entropy & 4.1223 & 1.1461 \\
Rosenbluth Index & 0.0276 & 0.0270 \\
\hline
\end{tabular}

Note: There are 275 MSA and CMSA observations.

Appendix Table 2. Regression Results: Manufacturing Subsectors (Concentration Ratio).

\begin{tabular}{|c|c|c|c|c|c|c|c|c|c|c|c|}
\hline Subsector & Obs. & $\mathrm{R}^{2}$ & Intercept & $\begin{array}{c}\text { Base Year } \\
\text { Subsector } \\
\text { Employment } \\
\end{array}$ & $\begin{array}{c}\text { Subsector } \\
\text { Concentration } \\
\text { (Conc. Ratio) }\end{array}$ & $\begin{array}{c}\text { Manufacturing } \\
\text { Concentration } \\
\text { Conc. Ratio) } \\
\end{array}$ & $\begin{array}{c}\text { Manufacturing } \\
\text { Diversity }\end{array}$ & $\begin{array}{c}\text { Subsector } \\
\text { Specialization } \\
\text { (Loc. Quot.) }\end{array}$ & South & Midwest & West \\
\hline 20 & 190 & 0.1888 & + & $-* *$ & - & - & - & + & $+*$ & $+* *$ & $+* *$ \\
\hline 21 & 1 & n.a. & & & $\leftarrow---$ & $---b i a$ & sed --- & ---- & $\rightarrow$ & & \\
\hline 22 & 43 & 0.8605 & $+*$ & $-* *$ & $-* *$ & + & - & - & + & + & $+*$ \\
\hline 23 & 112 & 0.3742 & - & $-* *$ & + & + & - & - & $+*$ & $+\dagger$ & $+* *$ \\
\hline 24 & 208 & 0.2828 & + & $-* *$ & $-\dagger$ & + & - & $-*$ & $+* *$ & $+* *$ & $+*$ \\
\hline 25 & 101 & 0.5542 & + & $-* *$ & - & + & - & $+* *$ & + & $+* *$ & $+*$ \\
\hline 26 & 69 & 0.5641 & $+\dagger$ & $-* *$ & - ** & - & - & $+* *$ & $+* *$ & $+* *$ & $+* *$ \\
\hline 27 & 253 & 0.7233 & $+* *$ & $-* *$ & $-* *$ & + & - & + & $+\dagger$ & $+*$ & $+*$ \\
\hline 28 & 118 & 0.4612 & $+* *$ & $-* *$ & $-* *$ & - & - & + & + & + & $+\dagger$ \\
\hline 29 & 31 & 0.6011 & + & $-* *$ & + & + & + & + & + & + & - \\
\hline 30 & 117 & 0.2423 & $+*$ & - & $-* *$ & + & - & - & $+* *$ & $+* *$ & $+* *$ \\
\hline 31 & 22 & 0.8803 & + & $-* *$ & - & - & + & + & $+\dagger$ & $+\dagger$ & $+\dagger$ \\
\hline 32 & 157 & 0.5617 & + & $-* *$ & - & - & - & - & $+*$ & $+* *$ & $+* *$ \\
\hline 33 & 70 & 0.5779 & + & $-* *$ & - & - & - & $+\dagger$ & $+\dagger$ & $+* *$ & + \\
\hline 34 & 200 & 0.2580 & + & $-* *$ & $-* *$ & + & - & + & $+* *$ & $+* *$ & $+* *$ \\
\hline 35 & 225 & 0.3708 & + & $-* *$ & $-* *$ & - & - & + & $+* *$ & $+* *$ & $+* *$ \\
\hline 36 & 115 & 0.1367 & + & $-*$ & - & + & - & + & $+*$ & $+*$ & $+* *$ \\
\hline 37 & 110 & 0.8619 & - & $-* *$ & + & - & + & $+*$ & + & $+*$ & + \\
\hline 38 & 84 & 0.6908 & $+* *$ & $-* *$ & $-* *$ & + & + & + & + & + & + \\
\hline 39 & 131 & 0.7283 & $+* *$ & $-* *$ & $-* *$ & - & $-\dagger$ & $-\dagger$ & + & + & $+* *$ \\
\hline
\end{tabular}

$\uparrow$ Significant at the $10 \%$ confidence level. $*$ Significant at the $5 \%$ confidence level. $* *$ Significant at the $1 \%$ confidence level. 
Appendix Table 3. Regression Results: Manufacturing Subsectors (Herfindahl-Hirschman).

\begin{tabular}{|c|c|c|c|c|c|c|c|c|c|c|c|}
\hline Subsector & Obs. & $\mathrm{R}^{2}$ & Intercept & $\begin{array}{c}\text { Base Year } \\
\text { Subsector } \\
\text { Employment }\end{array}$ & $\begin{array}{c}\text { Subsector } \\
\text { Concentration } \\
\text { (Herf.-Hirsch.) }\end{array}$ & $\begin{array}{l}\text { Manufacturing } \\
\text { Concentration } \\
\text { (Herf.-Hirsch.) }\end{array}$ & $\begin{array}{c}\text { Manufacturing } \\
\text { Diversity }\end{array}$ & $\begin{array}{c}\text { Subsector } \\
\text { Specialization } \\
\text { (Loc. Quot.) }\end{array}$ & South & Midwest & West \\
\hline 20 & 190 & 0.1833 & - & $-* *$ & - & + & - & $+\dagger$ & $+*$ & $+* *$ & $+* *$ \\
\hline 21 & 1 & n.a. & & & $\leftarrow---$ & ---- bia & sed --- & ----- & $\rightarrow$ & & \\
\hline 22 & 43 & 0.8450 & + & $-* *$ & $-*$ & + & + & - & + & - & $+t$ \\
\hline 23 & 112 & 0.3718 & - & $-* *$ & + & + & - & - & $+*$ & $+*$ & $+* *$ \\
\hline 24 & 208 & 0.2761 & + & $-* *$ & - & + & - & $-*$ & $+* *$ & $+* *$ & $+*$ \\
\hline 25 & 101 & 0.5504 & + & $-* *$ & - & + & - & $+* *$ & $+\dagger$ & $+* *$ & $+*$ \\
\hline 26 & 69 & 0.5286 & + & $-* *$ & $-\dagger$ & - & - & $+*$ & $+*$ & $+* *$ & $+* *$ \\
\hline 27 & 253 & 0.6748 & $+* *$ & $-* *$ & $-* *$ & + & - & + & $+^{*}$ & $+*$ & $+* *$ \\
\hline 28 & 118 & 0.4156 & + & $-* *$ & $-* *$ & - & - & + & $+\dagger$ & $+\dagger$ & $+^{*}$ \\
\hline 29 & 31 & 0.6204 & - & $-* *$ & - & - & + & $+\dagger$ & + & + & - \\
\hline 30 & 117 & 0.1913 & + & + & $-*$ & + & - & - & $+* *$ & $+* *$ & $+* *$ \\
\hline 31 & 22 & 0.8422 & - & $-* *$ & + & - & + & + & + & + & + \\
\hline 32 & 157 & 0.5570 & + & - ** & - & - & - & - & $+*$ & $+* *$ & $+* *$ \\
\hline 33 & 70 & 0.6217 & + & $-* *$ & $-* *$ & - & - & $+*$ & $+*$ & $+* *$ & + \\
\hline 34 & 200 & 0.2392 & - & - ** & $-*$ & + & - & + & $+* *$ & $+* *$ & $+* *$ \\
\hline 35 & 225 & 0.3479 & - & $-* *$ & - & - & - & + & $+* *$ & $+* *$ & $+* *$ \\
\hline 36 & 115 & 0.1460 & - & $-*$ & $-\dagger$ & - & - & + & $+*$ & $+*$ & $+* *$ \\
\hline 37 & 110 & 0.8622 & - & $-* *$ & + & - & + & $+*$ & + & $+*$ & + \\
\hline 38 & 84 & 0.6817 & + & - ** & $-* *$ & + & - & + & - & + & + \\
\hline 39 & 131 & 0.6948 & $+*$ & - ** & $-\dagger$ & + & $-{ }^{*}$ & $-^{*}$ & + & $+*$ & $+* *$ \\
\hline
\end{tabular}

+ Significant at the $10 \%$ confidence level. * Significant at the $5 \%$ confidence level. ** Significant at the $1 \%$ confidence level.

Appendix Table 4. Regression Results: Manufacturing Subsectors (Rosenbluth).

\begin{tabular}{|c|c|c|c|c|c|c|c|c|c|c|c|}
\hline Subsector & Obs. & $\mathrm{R}^{2}$ & Intercept & $\begin{array}{c}\text { Base Year } \\
\text { Subsector } \\
\text { Employment }\end{array}$ & $\begin{array}{c}\text { Subsector } \\
\text { Concentration } \\
\text { (Rosenbluth) }\end{array}$ & $\begin{array}{c}\text { Manufacturing } \\
\text { Concentration } \\
\text { (Rosenbluth) }\end{array}$ & $\begin{array}{c}\text { Manufacturing } \\
\text { Diversity }\end{array}$ & $\begin{array}{c}\text { Subsector } \\
\text { Specialization } \\
\text { (Loc. Quot.) }\end{array}$ & South & Midwest & West \\
\hline 20 & 190 & 0.1853 & - & - ** & - & - & - & $+t$ & $+*$ & $+* *$ & $+* *$ \\
\hline 21 & 1 & n.a. & & & $\leftarrow---$ & --- bia & sed --- & ---- & $\rightarrow$ & & \\
\hline 22 & 43 & 0.8542 & + & $-* *$ & $-*$ & $++^{+}$ & + & -+ & + & + & $+*$ \\
\hline 23 & 112 & 0.3714 & - & - ** & + & + & - & - & $+*$ & $+*$ & $+* *$ \\
\hline 24 & 208 & 0.2894 & + & $-* *$ & -+ & + & - & $-*$ & $+* *$ & $+* *$ & $+*$ \\
\hline 25 & 101 & 0.5825 & - & $-* *$ & - & $-*$ & + & $+* *$ & $+*$ & $+* *$ & $+* *$ \\
\hline 26 & 69 & 0.5480 & + & - ** & - & - & - & $+*$ & $+* *$ & $+* *$ & $+* *$ \\
\hline 27 & 253 & 0.6722 & $+* *$ & $-* *$ & - ** & - & - & - & + & $+*$ & $+*$ \\
\hline 28 & 118 & 0.4540 & ++ & $-* *$ & $-* *$ & - & - & + & ++ & ++ & $+*$ \\
\hline 29 & 31 & 0.6083 & - & $-* *$ & + & - & + & + & + & + & + \\
\hline 30 & 117 & 0.1978 & + & + & - & - & + & - & $+* *$ & $+* *$ & $+*$ \\
\hline 31 & 22 & 0.8457 & - & $-* *$ & - & - & + & + & + & + & + \\
\hline 32 & 157 & 0.5735 & + & $-* *$ & - & - & - & + & $+*$ & $+* *$ & $+* *$ \\
\hline 33 & 70 & 0.6107 & + & - ** & - * & - & - & $+*$ & $+*$ & $+* *$ & + \\
\hline 34 & 200 & 0.2352 & - & $-* *$ & - & - & + & + & $+* *$ & $+* *$ & $+* *$ \\
\hline 35 & 225 & 0.3630 & - & - ** & - & -+ & + & + & $+* *$ & $+* *$ & $+* *$ \\
\hline 36 & 115 & 0.1451 & - & $-*$ & - & - & - & + & $+*$ & $+*$ & $+* *$ \\
\hline 37 & 110 & 0.8742 & - & $-* *$ & - & $-* *$ & + & $+* *$ & + & + & + \\
\hline 38 & 84 & 0.6881 & + & - ** & $-*$ & - & + & + & - & + & + \\
\hline 39 & 131 & 0.7031 & $+*$ & - ** & - & - & - & -+ & + & ++ & $+* *$ \\
\hline
\end{tabular}

+ Significant at the $10 \%$ confidence level. * Significant at the $5 \%$ confidence level. $* *$ Significant at the $1 \%$ confidence level. 
Appendix Table 5. Regression Results: Manufacturing Subsectors (Theil's Entropy).

\begin{tabular}{|c|c|c|c|c|c|c|c|c|c|c|c|}
\hline Subsector & Obs. & $\mathrm{R}^{2}$ & Intercept & $\begin{array}{c}\text { Base Year } \\
\text { Subsector } \\
\text { Employment }\end{array}$ & $\begin{array}{c}\text { Subsector } \\
\text { Concentration } \\
\text { (Theil's Ent.) }\end{array}$ & $\begin{array}{l}\text { Manufacturing } \\
\text { Concentration } \\
\text { (Theil's Ent.) }\end{array}$ & $\begin{array}{c}\text { Manufacturing } \\
\text { Diversity }\end{array}$ & $\begin{array}{c}\text { Subsector } \\
\text { Specialization } \\
\text { (Loc. Quot.) }\end{array}$ & South & Midwest & West \\
\hline 20 & 190 & 0.1866 & - & - ** & + & - & $-\dagger$ & ++ & $+*$ & $+* *$ & $+* *$ \\
\hline 21 & 1 & n.a. & & & $\leftarrow----$ & $----b i$ & ed --- & ---- & $\rightarrow$ & & \\
\hline 22 & 43 & 0.8671 & - & $-* *$ & $+* *$ & - & - & - & + & + & $+*$ \\
\hline 23 & 112 & 0.3717 & - & - ** & + & - & - & - & $+*$ & $+*$ & $+* *$ \\
\hline 24 & 208 & 0.2794 & + & $-* *$ & + & - & - & $-*$ & $+*$ & $+* *$ & $+*$ \\
\hline 25 & 101 & 0.5464 & - & - ** & + & - & - & $+* *$ & + & $+* *$ & $+*$ \\
\hline 26 & 69 & 0.5571 & $-{ }^{*}$ & - ** & $+*$ & + & - & $+* *$ & $+* *$ & $+* *$ & $+* *$ \\
\hline 27 & 253 & 0.7546 & $-* *$ & - ** & $+* *$ & + & - & + & $+*$ & $+*$ & $+*$ \\
\hline 28 & 118 & 0.4865 & $-* *$ & - ** & $+*$ & ++ & + & $+\dagger$ & $+t$ & ++ & $+*$ \\
\hline 29 & 31 & 0.6014 & + & - *** & + & - & + & + & + & + & + \\
\hline 30 & 117 & 0.2505 & - & - & $+* *$ & - & - & - & $+* *$ & $+* *$ & $+* *$ \\
\hline 31 & 22 & 0.9010 & $-*$ & - ** & - & $+*$ & + & $+*$ & + & ++ & $+*$ \\
\hline 32 & 157 & 0.5687 & -+ & - ** & + & ++ & - & - & $+*$ & $+* *$ & $+* *$ \\
\hline 33 & 70 & 0.6051 & $+*$ & - ** & $+*$ & $-*$ & - ** & + & $+* *$ & $+* *$ & ++ \\
\hline 34 & 200 & 0.2878 & - & - ** & $+* *$ & - ** & - & + & $+* *$ & $+* *$ & $+* *$ \\
\hline 35 & 225 & 0.3843 & $-*$ & - ** & $+* *$ & + & - & $+\dagger$ & $+* *$ & $+* *$ & $+* *$ \\
\hline 36 & 115 & 0.1421 & + & - & + & - & - & - & $+*$ & $+*$ & $+* *$ \\
\hline 37 & 110 & 0.8623 & - & - ** & - & + & + & $+*$ & + & $+*$ & + \\
\hline 38 & 84 & 0.7066 & - & - ** & $+* *$ & + & + & $+\dagger$ & + & + & + \\
\hline 39 & 131 & 0.7435 & $-*$ & - ** & $+*$ & $+*$ & - & - & + & ++ & $+* *$ \\
\hline
\end{tabular}

+ Significant at the $10 \%$ confidence level. * Significant at the $5 \%$ confidence level. ** Significant at the $1 \%$ confidence level.

Appendix Table 6. Production Function Variables and Sources.

\begin{tabular}{|c|c|c|c|c|}
\hline Category & \multicolumn{2}{|c|}{ Variable } & \multirow{2}{*}{$\begin{array}{l}\text { Description } \\
\text { value of output }\end{array}$} & \multirow{2}{*}{$\begin{array}{l}\text { Source } \\
\text { LRD }\end{array}$} \\
\hline dependent variable & Q & output & & \\
\hline \multirow[t]{4}{*}{ standard inputs } & $\mathrm{K}$ & capital & gross book assets plus (capitalized) rentals & LRD \\
\hline & $\mathrm{L}$ & labor & production-worker-equivalent hours & LRD \\
\hline & $\mathrm{E}$ & energy & value of electricity and fuels & LRD \\
\hline & M & materials & value of purchased materials and services & LRD \\
\hline dominance & $\mathrm{D}$ & dominance & percent of shipments in dominator firms & LRD \\
\hline agglomeration & LP & labor pooling & percent of local employment in top industry occupations & Census, BLS \\
\hline \multirow[t]{4}{*}{ economies } & $\mathrm{SP}$ & inputs pooling & local employment in input supply industries & LBD, BEA \\
\hline & SD & producer services & local employment in producer service industries & LBD, BEA \\
\hline & RS & research & university research expenditures in industry-relevant fields & NSF \\
\hline & PS & patents & per capita industry-relevant patent rate & USPTO \\
\hline \multirow[t]{12}{*}{ controls } & $\mathrm{DE}$ & dominator & dummy: establishment belongs to dominant firm & LRD \\
\hline & SE & small & dummy: shipments less than 10 percent of smallest dominator & LRD \\
\hline & CR1 & region & dummy: South Census Region & Census \\
\hline & CR2 & region & dummy: Midwest Census Region & Census \\
\hline & CR3 & region & dummy: West Census Region & Census \\
\hline & POP & population & population density (persons per square mile) & Census \\
\hline & UE & unemployment & unemployment rate & BLS \\
\hline & INC & income & median household income in region (nominal dollars) & Census \\
\hline & ED & education & percent 25 or older in region with bachelor's degree or higher & Census \\
\hline & DV & diversity & Herfindahl index of regional industrial diversity (concentration) & LBD \\
\hline & $\mathrm{DH}$ & historic dominance & dominance in earlier year & LRD \\
\hline & DVH & historic diversity & diversity (concentration) in earlier year & LBD \\
\hline
\end{tabular}


Appendix Table 7. Production Function Estimates, Omitting Concentration or Diversity.

\begin{tabular}{ccccc|c}
\hline Industry & Year & $\begin{array}{c}\text { Concentration } \\
\text { (Conc. Ratio) }\end{array}$ & $\begin{array}{l}\text { Diversity Omitted } \\
\text { Concentration } \\
\text { (Herf.-Hirsch.) }\end{array}$ & $\begin{array}{c}\text { Concentration } \\
\text { (Rosenbluth) }\end{array}$ & $\begin{array}{c}\text { Concentration } \\
\text { Omitted } \\
\text { Diversity }\end{array}$ \\
\hline \multirow{3}{*}{30} & 1992 & -0.0345 & -0.1315 & $-0.7215 * *$ & $1.5621 *$ \\
& 1997 & -0.0489 & -0.0580 & $-0.5811 * *$ & $-1.8025 *$ \\
& 2002 & $-0.0676+$ & $-0.4655 * *$ & $-0.9829 * *$ & -0.5724 \\
354 & 1992 & $-0.0942 *$ & -0.1433 & $-0.3605+$ & $-3.0432 *$ \\
& 1997 & $-0.1970 * *$ & $-0.2084 * *$ & $-0.6801 * *$ & $-3.5475 * *$ \\
382 & 1992 & $-0.2075 * *$ & $-0.3112 * *$ & $-0.7843 * *$ & $-2.9836 *$ \\
& 1997 & $-0.4659 * *$ & $-0.9587 * *$ & $-2.7408 * *$ & $-27.8092 * *$ \\
& 2002 & $-0.3482 * *$ & $-0.3574 *$ & $-1.9827 * *$ & $-10.8047 *$ \\
\end{tabular}

+ Significant at the $10 \%$ confidence level. * Significant at the 5\% confidence level. ** Significant at the $1 \%$ confidence level. 


\section{APPENDIX 2: Production Function Variable Construction.}

Units. Monetary values are thousands of nominal dollars. Time measures are thousands of hours.

Inputs and Output. Variables are calculated at the establishment level. Output $(Q)$ is the total value of shipments adjusted for inventories and work in progress:

$$
Q=T V S+(W I E-W I B)+(F I E-F I B) .
$$

TVS is the total value of shipments; WIE and WIB are work in progress at the end and beginning of the year; FIE and FIB are end-of-year and beginning-of-year finished product inventories.

Capital is constructed as a gross stock measure- the sum of end-of-year capital assets and capitalized building and machinery rental expenditures:

$$
K=T A E+\frac{B R}{B P R}+\frac{M R}{M P R} .
$$

$T A E$ is total end-of-year building and machinery assets; $B R$ is building rental expenditures; $M R$ is machinery rental expenditures; $B P R$ and $M P R$ are (unpublished) annual national 3-digit-SIC capital prices obtained from the Bureau of Labor Statistics averaged across asset categories.

Labor $(L)$ is production-worker-equivalent hours, derived as the ratio of total wages to production worker average hourly wages:

$$
L=\frac{W P+W N P}{(W P / P H)} .
$$

$W P$ and $W N P$ are production and non-production payrolls; $P H$ is production worker hours.

Energy $(E)$ is the sum of purchased electricity and fuel quantities:

$$
E=C F\left(\frac{1,000}{E P R}\right)+P E\left(\frac{3,412.705}{1,000}\right) .
$$

$P E$ is millions of British Thermal Units of purchased electricity; $C F$ is purchased fuels cost; $E P R$ is the average state-level industry-specific energy price from the U.S. Energy Information Administration State Energy Data System.

Materials $(M)$ is the total cost of materials, parts, contract work, resales, purchased services, and repairs, adjusted for changes in materials inventories:

$$
M=C P+C R+C W+C P C+R B+R M+(M I B-M I E) .
$$

$C P$ is materials and parts cost; $C R$ is expenditures for resales; $C W$ is contract work costs; $C P C$ is purchased communications services; $R B$ and $R M$ are building and machinery repairs; $M I B-M I E$ 
is the difference between beginning- and end-of-year materials inventories.

Capital costs are total capital assets adjusted by multiplying by (unpublished) Bureau of Labor Statistics capital asset prices and LRD-reported building and machinery rental costs. Labor costs are total wages and salaries plus supplemental labor expenditures. Energy costs are purchased electricity and fuels costs. Materials costs are identical to the quantity measure.

Agglomeration Economies. Labor pooling is measured as an establishment's access to workers with skills that roughly match the industry's expected occupational requirements:

$$
L P_{k x}=\sum_{c}\left(\frac{O_{c x}}{O_{c T}} d_{c k}^{-\alpha}\right)
$$

where $x$ is the study industry, $c$ indexes counties, $k$ is the target establishment's county, $O_{c x}$ is county $c$ 's residential workforce in the top 15 occupations employed by industry $x$ nationally (identified from the Bureau of Labor Statistics national staffing matrix). $O_{c T}$ is county $c$ 's total workforce, and $d_{c k}$ is the distance between the centroids of county $c$ and the county of the target establishment for distances up to 75 miles and zero otherwise. Values of $O_{c}$ and $O_{T c}$ are from the 1990 and 2000 Census Equal Employment Opportunity tabulations.

Potential supply pools of manufactured inputs and producer services are calculated by weighting the local presence of supplier industries by the importance of each industry as a supplier to the study industry at the national level. Manufacturing input supply pooling is:

$$
S P_{k x}=\sum_{c}\left(\left(\sum_{m} \frac{E_{c m} P_{x m}}{P_{x M}}\right) \cdot d_{c k}^{-\alpha}\right)
$$

where $m$ indexes manufacturing industries, $E_{c m}$ is county $c$ 's employment in industry $m, P_{x m}$ is the dollar amount that the study industry purchases nationally from supplier industry $m, P_{x M}$ is the study industry's total national purchases from the manufacturing sector, and the other notations are the same as for labor pooling. Producer services pooling has nearly the same formula except that purchases and local employment refer to suppliers of producer services:

$$
S D_{k x}=\sum_{c}\left(\left(\sum_{s} \frac{E_{c s} P_{x s}}{P_{x S}}\right) \cdot d_{c k}^{-\alpha}\right)
$$

where $s$ indexes producer services industries and $P_{x S}$ is the study industry's total national purchases of producer services. Purchase amounts are derived from the Make and Use tables of the Benchmark Input-Output Accounts from the Bureau of Economic Analysis. $E_{c m}$ and $E_{c s}$ are 
tabulated from the Longitudinal Business Database, another confidential establishment-level Census dataset that covers most economic sectors but lacks full input and output information.

Two variables indicate different types of knowledge spillovers. The first gauges regional access to relevant basic research and knowledge:

$$
R S_{k x}=\sum_{c}\left(\left(\sum_{f} R_{c f}\right) \cdot d_{c k}^{-\alpha}\right)
$$

where $f$ indexes industry-relevant academic fields, $R_{c f}$ is the total amount of research expenditures in academic field $f$ during the previous five years at research universities located in county $c$, and the other variables are as described above. The maximum distance is set at 200 miles. The academic fields relevant to each industry are modified from Cohen et al. (2002), and annual university research expenditures are from the National Science Foundation's CASPAR database. The second measure uses patents to indicate private sector research activity and regional innovative culture, weighting the volume of patents in each technology classification by the relative importance of those technology categories to the target industry:

$$
P S_{r x}=\sum_{g \in K}\left(\frac{P A T_{g r}}{P O P_{r}} N_{g x}\right)
$$

where $g$ indexes patent technology classifications, $r$ signifies the region, $x$ represents the study industry, $K$ is the set of patent technology classifications relevant to the study industry (both directly and via cross-industry spillovers), $P A T_{g r}$ is the number of utility patents granted within region $r$ in the last five years in patent technology class $g$ (from the CASSIS bibliographic system of the U.S. Patent and Trademark Office), $P O P_{r}$ is the regional residential population, and $N_{g x}$ is a relevance index developed from citation flows (Koo 2005). Industry-relevant patent technology classifications are identified from the USPTO technology-industry match and a technology flow matrix developed by Koo (2005).

Control Variables. Regional unemployment rates, household incomes, and population densities are constructed for LMAs by combining county-level estimates. Unemployment rates are from the Bureau of Labor Statistics Local Area Unemployment Statistics. Median household income levels are from Census Small Area Income and Poverty Estimates. Population density is calculated from Census population estimates. Establishment-level data from the LBD are used to construct regional industrial diversity and historic diversity measures. Because the LBD starts in 1977, the historic diversity measure for the 1992 sample is from 1977. 